Western University

Scholarship@Western

Centre for the Study of International Economic

Centre for the Study of International Economic

Relations Working Papers

Relations

1985

\title{
An Investigation of the Labor Market Earnings of Panamanian Males: Evaluating Sources of Inequality
}

James J. Heckman

V. Joseph Hotz

Follow this and additional works at: https://ir.lib.uwo.ca/economicscsier_wp

Part of the Economics Commons

Citation of this paper:

Heckman, James J., V. Joseph Hotz. "An Investigation of the Labor Market Earnings of Panamanian Males: Evaluating Sources of Inequality." Centre for the Study of International Economic Relations Working Papers, 8529C. London, ON: Department of Economics, University of Western Ontario (1985). 
THE CENTRE FOR THE STUDY OF INTERNATIONAL ECONOMIC RELATIONS

WORKING PAPER NO. 8529C

AN INVESTIGATION OF THE LABOR MARKET EARNINGS OF

PANAMANIAN MALES: EVALUATING SOURCES OF INEQUALITY

\author{
James J. Heckman \\ and \\ V. Joseph Hotz
}

This paper contains preliminary findings from research work still in progress and should not be quoted without prior approval of the authors.

DEPARTMENT OF ECONOMICS

THE UNIVERSITY OF WESTERN ONTARIO

LONDON, CANADA

N6A $5 \mathrm{C} 2$

Department of Economics Library

NOV 11985

University of Western Ontario 


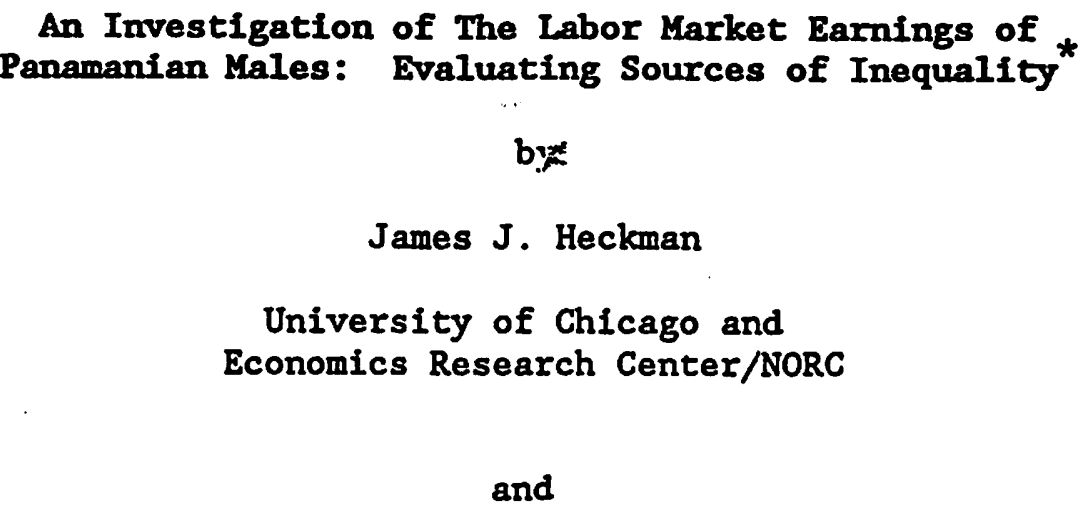

V. Joseph Hotz

University of Chicago and

Economics Research Center/NORC

First Draft: June 1985

Second Draft: August 1985

Bepartment of Fonionics librory
NOV 11985
University of Western Ontario

*We wish to thank Bo Honore for suggestions and research assistance as well as Gary Becker and Jacob Mincer for their comments on an earlier draft. 
This paper presents empirical evidence on the determinants of labor market earnings and inequality for males in Panama. Using newly available microdata from the U.N. sponsored Socioeconomic Survey of Panama conducted in 1983, we estimate earnings equations using the measurement framework develpped by Mincer (1974) and widely used In studies of the determinants of earnings. We compare our estimates for Panama with those for other countries at various stages of economic development. The primary focus of this paper is to examine empirical evidence on two aspects of inequality in less developed economies, namely labor market segmentation and social stratification. While we present several tets of the segmentation hypothesis, including several of the dual labor market hypothesis, we discuss the inherent problems of interpreting such tests. We also present evidence on the importance of family background in the determination of earnings and educational attainment for Panamanian males and compare it with that for the U.S. 


\section{Introduction}

This paper presents empirical evidence on the determinants of labor market earnings and inequality for males in Panama. Using newly available microdata from the U.N. sponsored Socioeconomic Survey of Panama conducted in 1983, we estimate earnings equations using the measurement framework developed by Mincer (1974) and widely used in studies of the determinants of earnings. 1 We compare our estimates for Panama with those for other countries at various stages of economic development.

The primary focus of this paper is to examine empirical evidence on two aspects of inequality in less developed economies, namely labor. market segmentation and social stratification. It is widely believed that in Latin American countries family origin plays a much stronger role in determining educational and labor market outcomes than it does in more advanced economies such as the U.S. The most frequently offered explanations for this phenomena stress greater state support for education and greater opportunities for job mobility and training in a more advanced economies. It is also widely believed that markets are segmented with the poor confined to a labor market distinct from that engaged in by the middle class. As noted by Cain (1976), it is difficult to test such theories, in part because they are poorly formulated statistical hypotheses and in part because critical data on mobility between sectors do not exist.

The plan of this paper is as follows. We first discuss Mincer's earnings equation and related models for the determination of earnings. We briefly survey the relevant published literature on empirical earnings functions with an eye toward producing an empirical benchmark against which we can measure our 
results for Panama. Next we describe our estimates for the country as a whole and compare these estimates with similar specifications for data from other countries.

We next consider evidence on the extent of labor market segmentation in Panama. First, we compare earnings regressions for the country as a whole with those for separate regions of the country. In a small country the size of Panama, it is plausible that there would be no geographical segmentation; estimated earnings equations for regions would be expected to be similar. Evidence to the contrary would indicate the importance of separate markets within the country and hence a form of segmentation. A second version of the segmentation hypothesis, which we also test, suggests that poor people are in.a different market than others. This type of segmentation hypothesis is sometimes called the dual labor market hypothesis. As noted by Cain (1976) and reemphasized by us below, testing this hypothesis raises delicate econometric problems.

The "obvious" way to test this hypothesis splits the population into two groups: the poor and the rest. If the earnings functions differ for these two groups, it would appear that they are in separate markets. Such a procedure has been advocated and pursued in the 1iterature. (See Cain (1976), for a survey of these papers.) There are, however, three problems with this approach. First, by selecting samples on the basis of the dependent variable (earnings), sample selection bias can be induced in the estimates causing the poor to look different from the rest. Second, even if there were two distinct earnings equations, biased estimates and tests result if the wrong definition of poverty is used. By picking the wrong cut off point for income for defining the poverty population, it is possible to produce estimates of earnings functions for two erroneously labeled sectors which are biased toward similarity. Third, if the true functional form of the earnings function is not known (as it usually is 
not) and is, in fact, misspecifled, evidence showing separate regressions for each group, after correcting for selection bias, may simply indicate misspecification of the functional form of the earnings equation. These questions are discussed and some tests are proposed and implemented.

Finally, we consider evidence on the social stratification hypothesis. We first examine the importance of family background varlables in determining labor market earnings. We discuss some ambiguity that arises in interpreting such evidence. Another aspect of stratification is the transfer of educational status across generations. We fit intergenerational mobility models for education and compare our findings with evidence from other countries. We find considerably greater evidence of stratification for Panama than for the U.S. -

\section{Models of Labor Earnings and Their Estimation}

A variety of models of labor earnings have been advanced in the literature. The two most prominent are the Mincer $(1958,1974)$ - Becker (1964) human capital model and the hedonic model developed by Tinbergen $(1951,1956)$ and popularized by Rosen (1974) and Sattinger (1980). Although the economic interpretation placed on earnings equations differs in these two models, they are empirically indistinguishable in a single cross section of data of the type at our disposal. The simple schooling model of Mincer (1958) writes:

$$
\text { lny }=\alpha_{0}+\alpha_{1} s+u
$$

where $\mathrm{ln}$ is natural logarithm, $\mathrm{y}$ is earnings and $\mathrm{s}$ is schooling, and $u$ is an error term for the model representing unobserved determinants of income. In one version of Mincer's model, in which everyone is alike in untralned earning capacity and opportunities, $\alpha_{1}$ can be interpreted as the market rate of interest. More generally, $\alpha_{1}$ can be interpreted as an average rate of return to 
schooling with $\alpha_{0}$ as the logarithm of the base earnings of an individual with no schooling. This second interpretatiot is based on a tautology that income equals initial endowment plus the average rate of return to investment multiplied by the volume of the invedtment.

In later work by Mincer (1974) and Becker and Chiswick (1966), this specification is augmented to include the effect of investment after formal schooling. In this specification the log of earnings is written as

$$
\text { lny }-\beta_{0}+\beta_{1} t+\beta_{2} t^{2}+u
$$

where $t$ and $t^{2}$ are, respectively, post school labor market experience and experience squared and $u$ is an unobserved error term. This basic equation can be and has been embellished to include hours of work, regional dummy variables and other variables. (see Chiswick (1974) or Mincer (1974)). Model (2) is the basic specification for earnings adopted in this study.

An alternative interpretation of (1) and (2) is as an "hedonic equation." Tinbergen (1956) derives $\log$ linear equations (1) and (2) from models in which heterogenous firms value productive attributes such as schooling and work experience and heterogenous workers supply themselves to the market. An implicit market for skills sorts workers and firms. The slope coefficients of (1) and (2) reveal the percentage change in price paid for extra units of the associated attribute. Tinbergen (1951) provides an excellent intuitive description of the process of equilibration in hedonic markets.

The precise economic interpretation placed on estimates of equations and (2) is of little concern to us here. Under either interpretation, these equations give equilibrium income relationships of the effects of changes in inputs on $\log$ income. Because it is more familiar we use the language of Mincer's framework, if only to facilitate the comparison of our empirical results with those reported by others. 
Following the traditions of a well established empirical 11terature, we estimate equations (1) and (2) and variants of these equations by ordinary least squares. Research by Griliches (1979) using data from the U.S. indicates that more sophisticated econometric methods that attempt to control for the endogeneity of schooling (1.e., that the the unobservables in earnings equations may influence schooling decisions) and for ability bias (a spurious relationship between income and schooling that may only be a consequence of the fact that people with greater market ability also get more schooling) do not alter the estimates of earnings and wage equations. Although it remains to be established that this is the case for Panamanian data, we use the conventional methodology if only to enhance the comparability of our estimates with those obtained for other countries.

\section{Estimates of the Schooling Model (Eq.(1))}

Table 1 reports estimates of the means and variances of $10 g$ earnings and schooling, and parameters of earnings equation (1) for Panamanian males age 25 64 in 1983 (see the bottom two rows of the table). To put these numbers in context, we report estimates of the same parameters for the U.S. as a whole, for the U.S. broken down into regional and racial groups, for Puerto Rico as a whole (1959) and urban Puerto Rico (1959), for a sample of urban Mexicans (1963), and for non-farm Canada (1961). All except the Panamian estimates are taken from Chiswick (1974). ${ }^{2}$

The estimates separate into two groups: those for the more economically developed countries and regions (Canada and the U.S.) and those for less developed regions (urban Mexico, Panama as a whole, Panama City and its

2. The numbers reported in Table 1 represent all of the evidence on the schooling model reported by Chiswick (1974). 


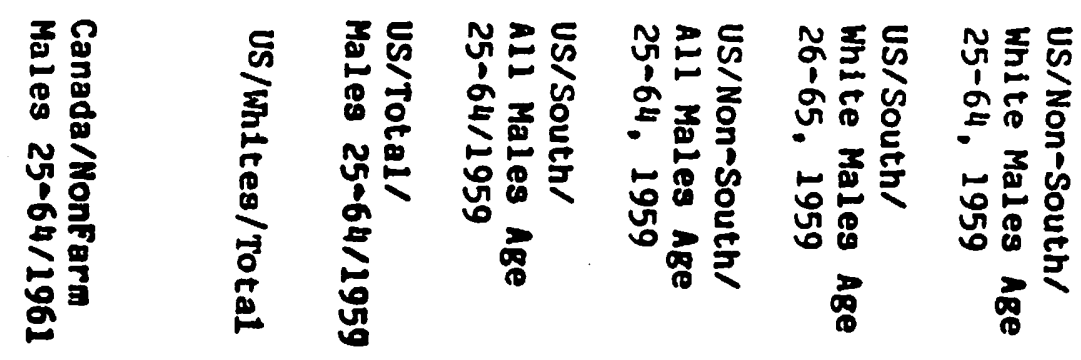

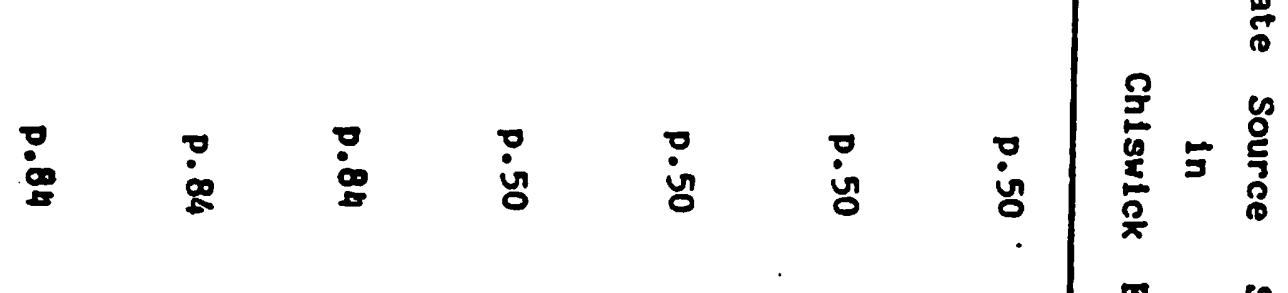

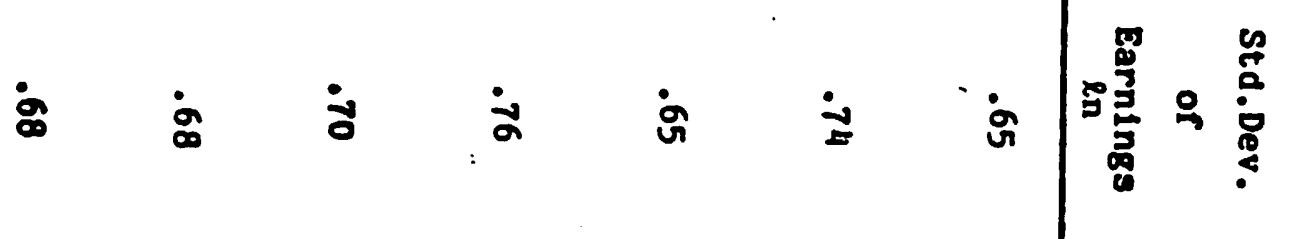

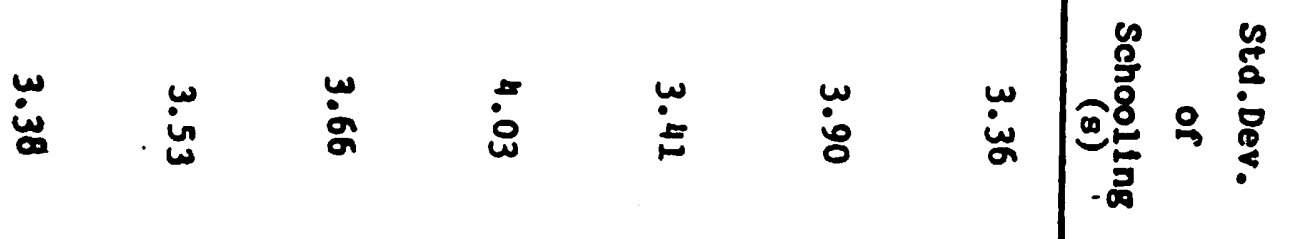

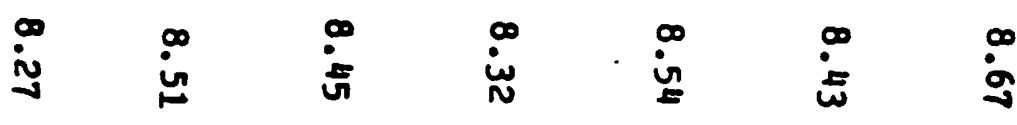

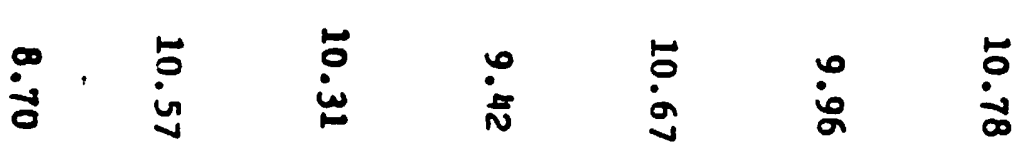

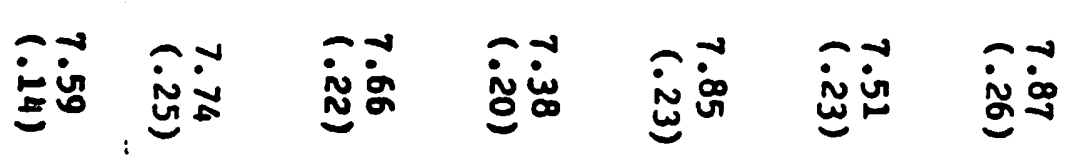

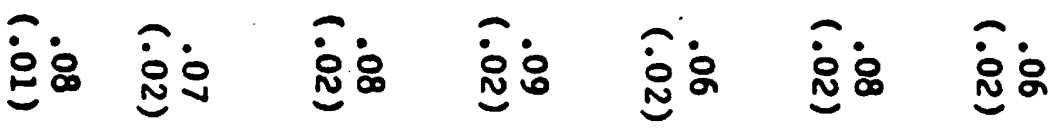

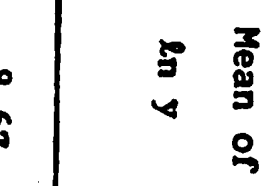




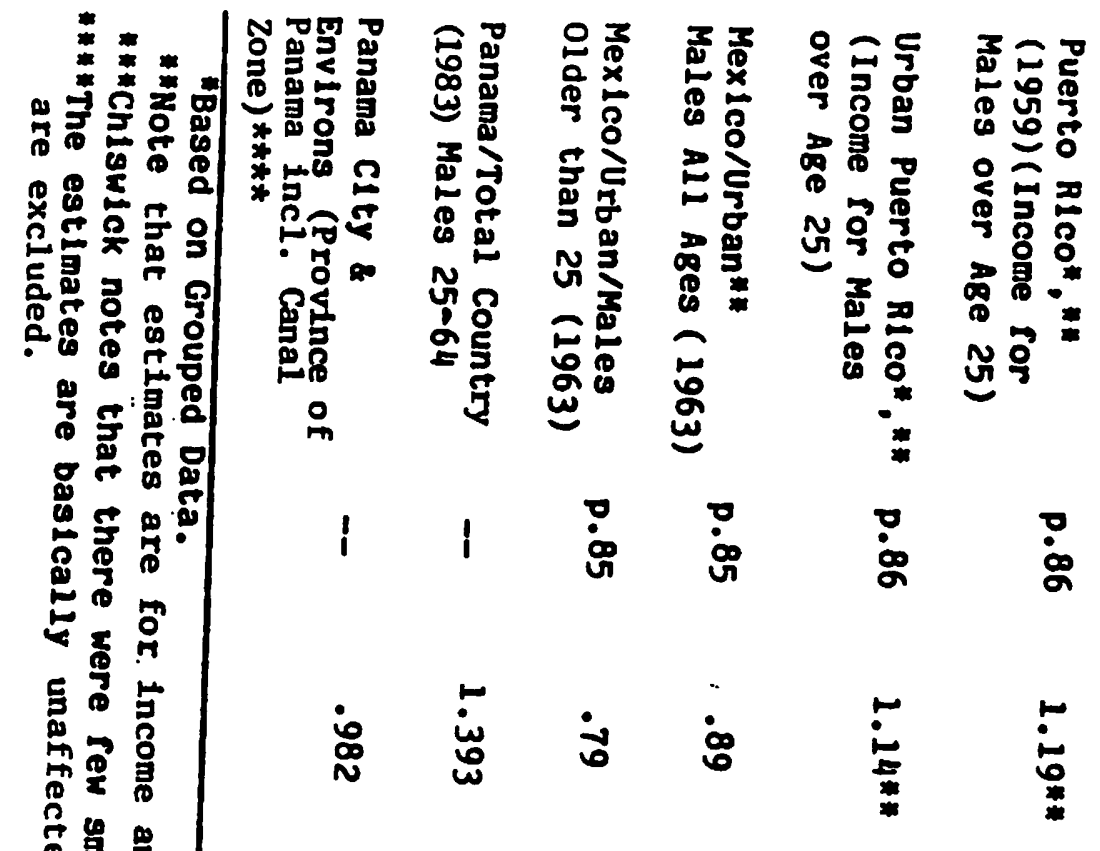

⿷

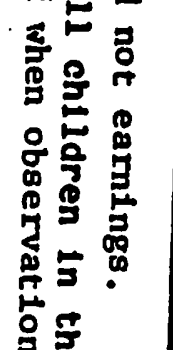

苗

요ㅇㅛㅛ

$\nabla 5$

뭉

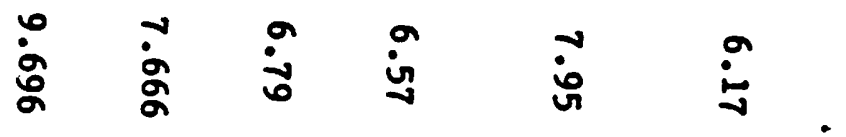

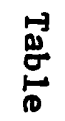

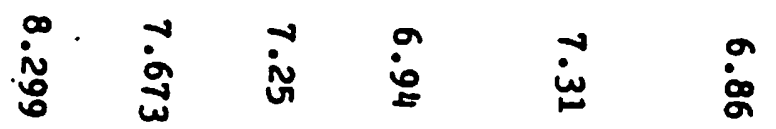

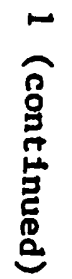

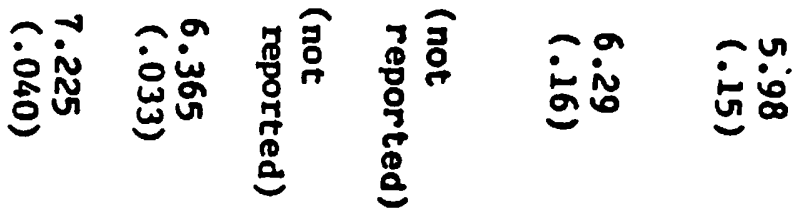

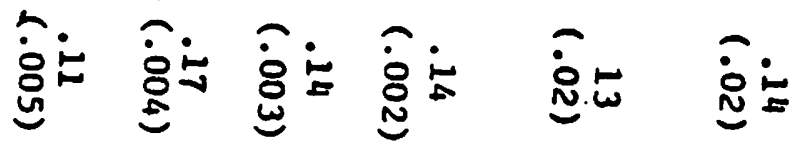

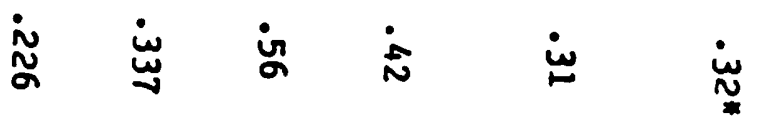

.

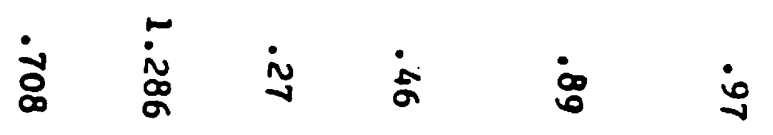


environs, and Puerto Rico.) Rates of return to schooling (values of $\alpha_{1}$ ), variability in earnings (measured by the standard deviation of $\log$ earnings) and variability in schooling levels (standard deviation of schooling) tend to be higher in less developed regions as do goodness of fits for the equation $\left(R^{2}\right)$. The same pattern is found comparing the results for Panama as a whole with the results for more urban (and developed) Panama City. Estimated rates of return to schooling are higher in Panama as a whole (.17) than in Panama City and environs (.11). The estimates reported in Table 1 clearly place Panama and Panama City squarely in the distribution of less developed countries in which the impact of schooling on earnings tends to be high.

\section{Estimates of the Rate of Return to Schooling}

Mincer (1974) has presented powerful theoretical and empirical reasons for augmenting the schooling model of equation (1) to include post school work experience or age. (Experience is proxied as age minus schooling.) For this reason, earnings function (2) has been widely used to generate estimates of the impact of a unit change of schooling on log earnings. Below, we report detailed estimates of models based on equation (2) as well as more elaborate specifications.

Before turning to a detailed discussion of such estimates, it is helpful to present our estimate of the rate of return to schooling based on equation (2) and compare it with estimates from other countries derived from the same methodology. We are aided in this task by the compilation of estinates of earnings function for males in Psacharopoulos (1981). Table 2 presents his results. Our estimate of the rate of return in Panama obtained from equation 
(2) is $12.568 .^{3}$ This estimate is below the average for all Latin American countries reported in Table 2. However, it is important to note that our estimate. is for 1983 whereas the estimates for the other Latin American countries are based on data as remote in time as 1963 . With continuing economic development, it is plausible that the 1983 rates of return for Mexico, Brazil and Columbia would be lower than the figures reported for the countries in Table 2. The estimated rate of return for Panama places it somewhere between the intermediate country and less developed category rates of return as computed by Psacharopoulos.

5. Estimates of Earnings Functions for the Country as a Whole and for Disaggregated Regions

We now turn to the results of an extensive empirical investigation of earnings functions for Panamanian non-farm males age 25-64. The analysis was conducted for individuals who report positive earnings in the survey year. More than 958 of the surveyed individual males had nonzero earnings so sample selection bias arising from deleting observations should not be a problem. Earnings consist of income from ordinary employment, including self employment income. Table 3 defines the variables used in these regressions and as well as those utilized in the analyses presented in this paper.

Table 4 records estimates for the country as a whole with parameters of a

3. This estimate is the partial derivative of $\ln$ earnings with respect to a change in education holding experience (- age minus schooling) and experience squared constant. The estimating equation used to secure the estimate regresses ln earning on education, age and age squared. Under different specifications (including reglonal dummy variables, variables measuring whether the worker has taken technical training, and family background variables) the estimated rate of return varies from .128 to .0781 . The number reported in the table presents the estimate obtained in using the same regression specification as is used to produce the other numbers in the table. 
Table 2

The Percent Inerenent in Earnings Associated with One Extra Year of Schooling

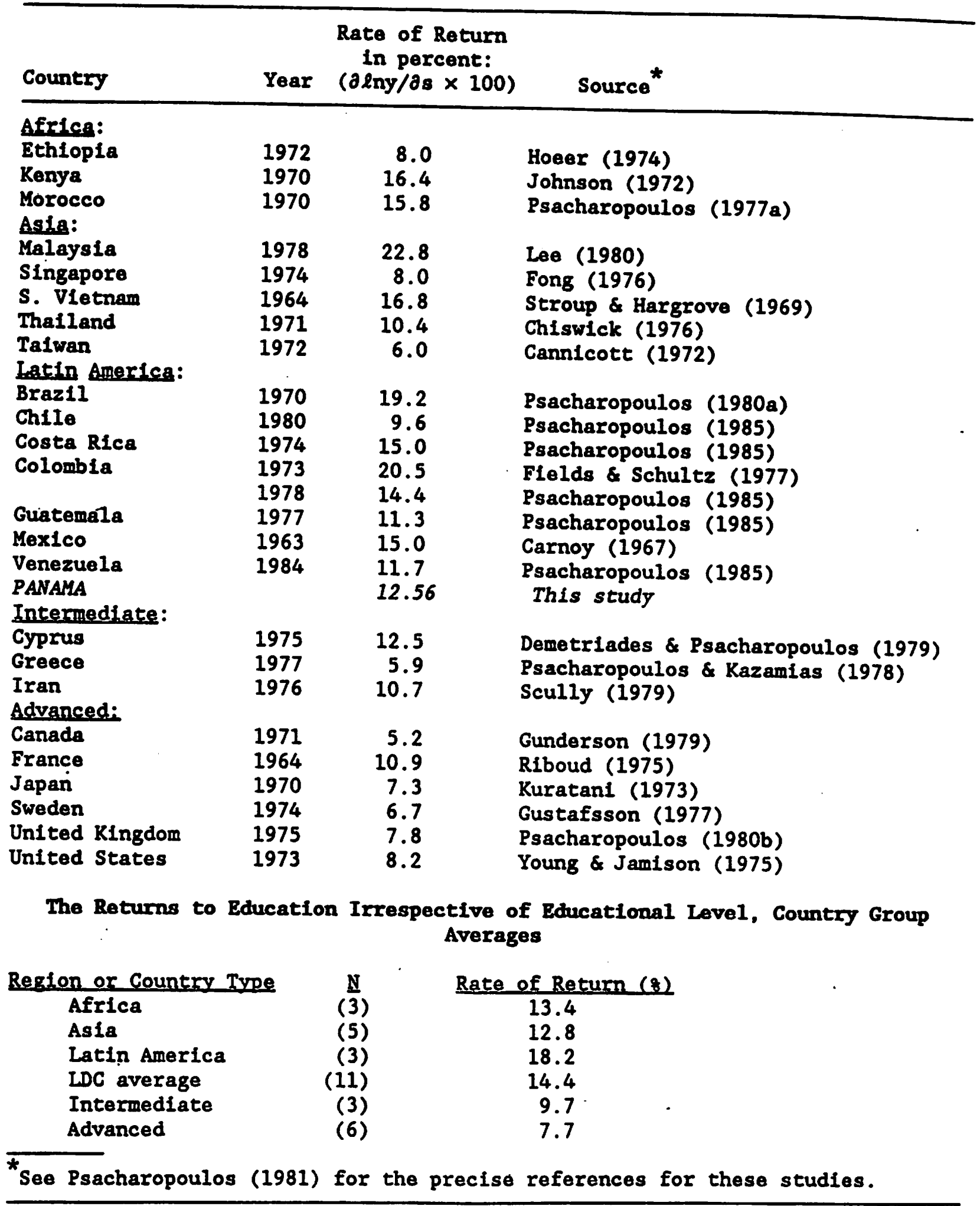


Table 3

Definitions of Variables

\begin{tabular}{|c|c|}
\hline $\ln$ Barn & $\begin{array}{l}\text { Natural logarithm of Annual Earnings in the Survey Period (- } \\
\text { Total Employment \& Self Employment Income) of Male Head }\end{array}$ \\
\hline Ed-Head & Number of School Years Completed by Male Head \\
\hline Age & Age of Male Head at Survey \\
\hline AgeSq & Age Squared \\
\hline Training & $\begin{array}{l}\text { Dummy Variable - } 1 \text { if Male Head received technical training, } 0 \\
\text { otherwise }\end{array}$ \\
\hline EmployIn & $\begin{array}{l}\text { Intensity of Employment - ratio of months employed in the last } 6 \\
\text { months in nonagricultural sector }\end{array}$ \\
\hline Bocas & $\begin{array}{l}\text { Dummy Variable - } 1 \text { if male head lives in Province of Bocas, } 0 \\
\text { otherwise }\end{array}$ \\
\hline Cocle & $\begin{array}{l}\text { Dummy Variable - } 1 \text { if male head lives in Province of Cocle, } 0 \\
\text { otherwise }\end{array}$ \\
\hline Chiriqui & $\begin{array}{l}\text { Dummy. Variable - } 1 \text { if male head lives in Province of Chiriqui, } 0 \\
\text { otherwise }\end{array}$ \\
\hline Darlen & $\begin{array}{l}\text { Dummy Variable - } 1 \text { if male head lives in Province of Darien, } 0 \\
\text { otherwise }\end{array}$ \\
\hline Herrera & $\begin{array}{l}\text { Dummy Variable - } 1 \text { if male head lives in Province of Herrera, } 0 \\
\text { otherwise }\end{array}$ \\
\hline Los Santo & $\begin{array}{l}\text { Dummy Variable - } 1 \text { if male head lives in Province of Los Santo, } 0 \\
\text { otherwise }\end{array}$ \\
\hline Veraguas & $\begin{array}{l}\text { Dummy Varlable }-1 \text { if male head lives in Province of Veraguas, } 0 \\
\text { otherwise }\end{array}$ \\
\hline Canal Zone & $\begin{array}{l}\text { Dummy Variable - } 1 \text { if male head lives in the Canal Zone, } 0 \\
\text { otherwise }\end{array}$ \\
\hline Urban & $\begin{array}{l}\text { Dummy Variable }=1 \text { if male head lives in an Urban Area, } 0 \\
\text { otherwise }\end{array}$ \\
\hline
\end{tabular}


Table 3 (Contimued)

\begin{tabular}{|c|c|}
\hline LowkEarn & $\begin{array}{l}\text { Dumay Variable - } 1 \text { if male head's annual earnings are below the } \\
\text { 25th percentile of the country's income distribution }\end{array}$ \\
\hline Ed*Low & Interaction of LowkEarn and Educ \\
\hline Age*Low & Interaction of LowkEarn and Age \\
\hline AgeS*Low & Interaction of LowtEarn and AgeSq \\
\hline Trn*Low & Interaction of LowtEarn and Training \\
\hline Boc*Low & Interaction of LowkEarn and Bocas \\
\hline Coc*Low & Interaction of LowkEarn and Cocle \\
\hline Col*Low & Interaction of LowkEarn and Colon \\
\hline Chi*Low & Interaction of Low*Earn and Chiriqui \\
\hline Dar*Low & Interaction of LowtEarn and Darien \\
\hline Her*Low & Interaction of LowkEarn and Herrera \\
\hline LosS*Low & Interaction of LowkEarn and Los Santo \\
\hline Vera*Low & Interaction of LowtEarn and Veraguas \\
\hline CanZ*Low & Interaction of Low*Earn and Canal-Zo \\
\hline Urb*Low & Interaction of LowtEarn and Urban \\
\hline LowtLow & Low*Earn Squared \\
\hline Ed-Wife & Number of School Years Completed by wife of male head \\
\hline Ed-Child & Number of School Years Completed by male head's oldest son \\
\hline Ed-Father & Number of School Years Completed by male head's father \\
\hline Ed-Mother & Number of School Years Completed by male head's mother \\
\hline
\end{tabular}


variety of specifications of the earnings function. For each specification, we estimate the implied rate of return ( $\partial$ lny/as), the number of years after schooling completion that earnings peak, and the rates of growth of earnings with experience (- age - schooling - 6) for varlous numbers of years of postschooling experience $(0,5,10,15,20,25$ years). Estimates for each region, reported in the same format as Table 4, are presented in the Appendix.

- Examining the estimates in Table 4 for the country as a whole, we find that estimated rates of return range from 7-128. The estimated rate of return falls as more variables included in the regression. In addition, the regional dummy varlables measured against the benchmark of Panama province (see Cols. (5) and (6)) indicate pronounced variations in regional earnings. Workers in the Canal Zone earn 40-508 more income than those outside the Zone. Workers in urban areas earn 558 more income. An $F$ test indicates that the regional and geographical dummy variables are strongly significant. 4

Table 5 summarizes the main features of alternative earnings function specifications for the country as a whole and by region. For the entire country, the peak in the earnings profile occurs 19-20 years after completing schooling. The rate of growth in earnings with experience starts at $3-48$ and after ten years slows to 1-28. Technical training raises earnings by 358 . Based on the individual region results, note the great range of variation in the estimates. Rates of return to schooling tend to be higher in less economically developed regions as do estimated effects of training on earnings. An F test for the hypothesis of equality of slope coefficients across regions (allowing separate intercepts in each region) is strongly rejected. Rates of return (in the. language of human capital theory) or implicit prices for attributes (in the

4. The F statistic is 84.87 with 10 and 4136 degrees of freedom. 

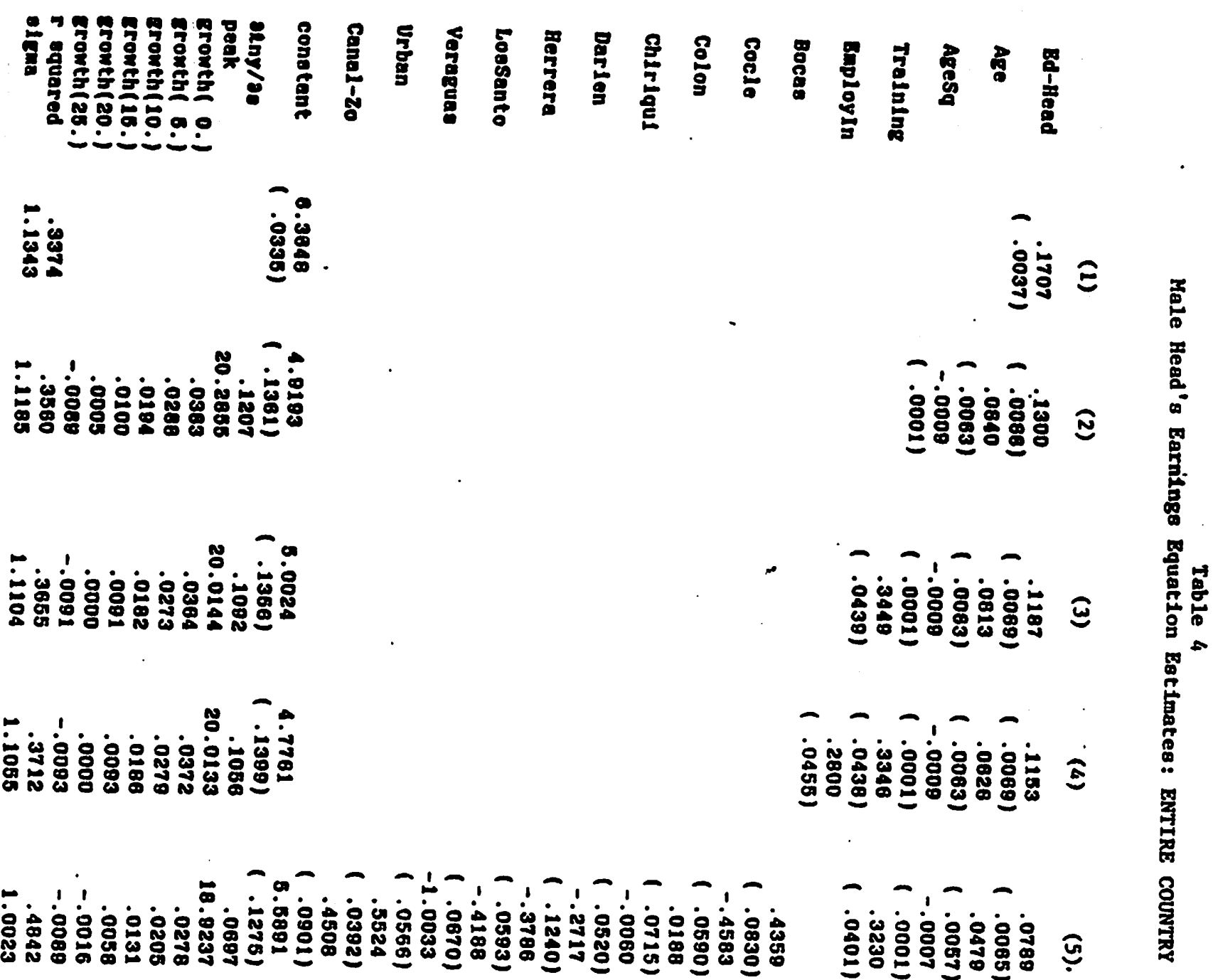

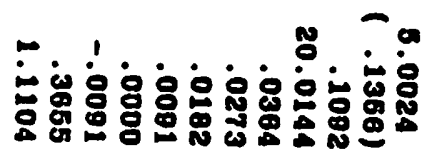

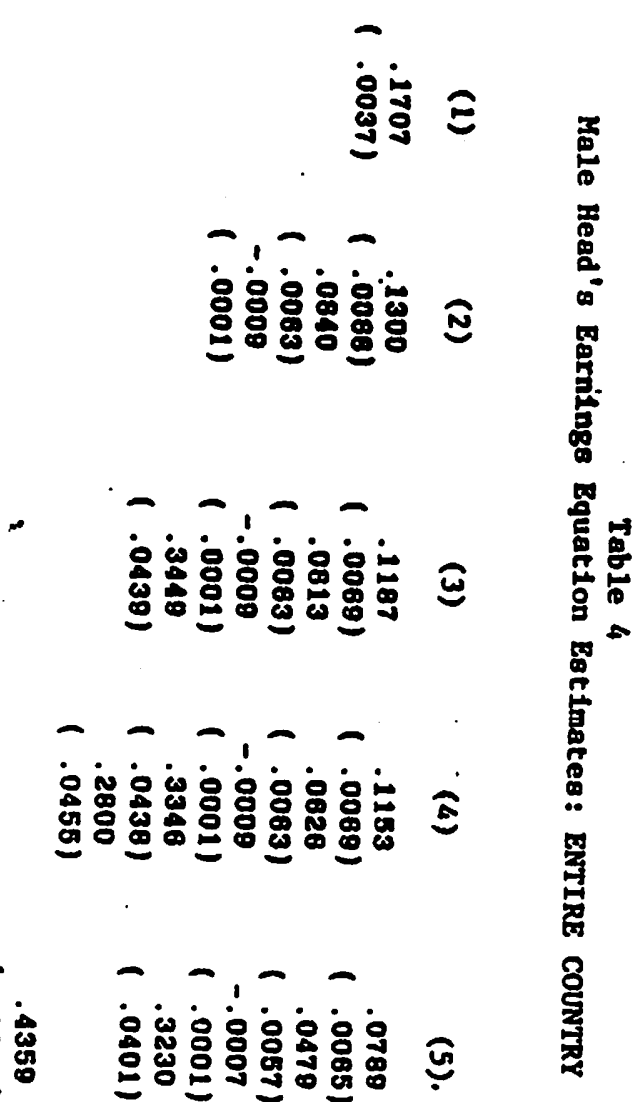

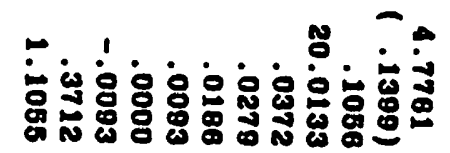

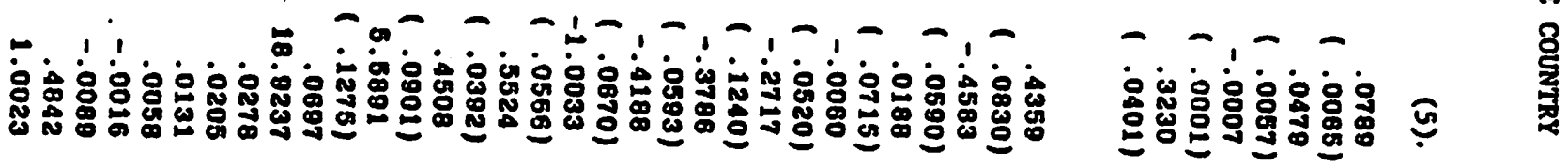

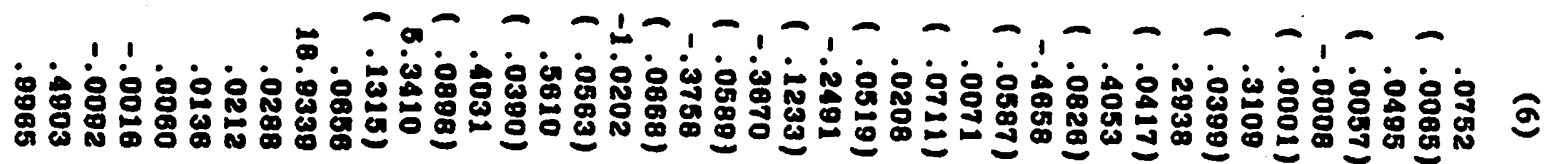


language of hedonic theory) differ greatly among regions. 5 Judging by these criteria, the Panamanian labor market is strongly geographically segmented.

\title{
Table 5
}

\begin{abstract}
Sumary of Results for Alternative Earnings Equation Specifications
\end{abstract}

\begin{tabular}{|c|c|c|c|c|c|c|}
\hline $\begin{array}{l}\text { Coographical } \\
\text { Regitan }\end{array}$ & 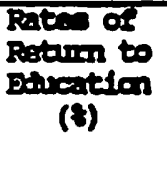 & $\begin{array}{l}\text { Paak in } \\
\text { Barnings } \\
\text { Proetle } \\
\text { (years since } \\
\text { schooling) }\end{array}$ & $\begin{array}{l}\text { Goith pate } \\
\text { schooling } \\
\text { canpletion } \\
\text { (8) }\end{array}$ & $\begin{array}{l}\text { In Enaning } \\
\text { at } 10 \text { Years } \\
\text { After School } \\
\text { ( }(\mathrm{f})\end{array}$ & $\begin{array}{l}\text { Partial Eefects } \\
\text { of Training } \\
\text { (?) }\end{array}$ & $\begin{array}{l}\text { Partial Eefects } \\
\text { of Untaen Exvirarment } \\
\text { (f) }\end{array}$ \\
\hline \multirow{5}{*}{ 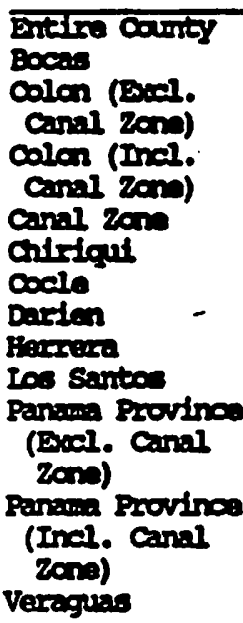 } & $\begin{array}{l}7-12 \\
6\end{array}$ & $\begin{array}{l}19-20 \\
31\end{array}$ & $\begin{array}{l}3-4 \\
4-3\end{array}$ & $\begin{array}{l}1-2 \\
3\end{array}$ & $\begin{array}{c}35 \\
\text { ingign." }\end{array}$ & $\begin{array}{c}55 \\
\text { insign. }\end{array}$ \\
\hline & $3-5$ & 18 & 4.7 & 2 & insign. & insign. \\
\hline & $\begin{array}{l}2-5 \\
3-5 \\
7-11 \\
8-12 \\
7-10 \\
8-16 \\
7-13\end{array}$ & $\begin{array}{l}18 \\
24 \\
32 \\
16-18 \\
9 \\
17-20 \\
14-21\end{array}$ & $\begin{array}{l}5 \\
2 \\
2-3 \\
3 \\
3 \\
3 \\
2\end{array}$ & $\begin{array}{l}2 \\
1.2 \\
1-2 \\
2 \\
1 \\
1-2 \\
.5-1\end{array}$ & $\begin{array}{c}\text { Insigg. } \\
27 \\
44 \\
70 \\
68 \\
56 \\
68\end{array}$ & $\begin{array}{c}\text { insign. } \\
\text { insign. } \\
35 \\
68 \\
\text { insign. } \\
92 \\
\text { insign. }\end{array}$ \\
\hline & $0^{8-9}$ & 26 & $2-3$ & 1 & 19 & 45 \\
\hline & $\begin{array}{l}8-10 \\
7-15\end{array}$ & $\begin{array}{l}30 \\
15-17\end{array}$ & $\begin{array}{l}2-3 \\
3.5-5\end{array}$ & $2^{1-2}$ & $\begin{array}{l}20 \\
68\end{array}$ & $\begin{array}{r}47 \\
102\end{array}$ \\
\hline 1 & 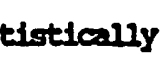 & gnificant & & & & \\
\hline
\end{tabular}

5. The F statistic is 14.43 with 48 and 4099 degrees of freedom. 
To compare our results with results from the U.S., consider the estimates of equation (2) given in column (2) of Table 4 and in all of the Appendix tables. The main features of these estimates are reported in Table 6 . The final row of the table presents estimates of the coefficients of this specification for U.S. data on males age 25-64 reported by Mincer (1974, p.92). The results for the country as a whole suggest that the rate of return to schooling is higher, the profile of earnings peaks earlier, and the rate of growth of earnings is slower than is the case for U.S. data. The slower rate of growth of earnings and the earlier peak suggests that there is less on-the-job investment in Panama than in the U.S. However, there are regions of Panama with earnings functions that more closely resemble those for the U.S. Not surprisingly, these regions tend to be the more modern, urban areas such as the Canal Zone, Panama City and Bocas.

\section{Testing the Dual Labor Market Hypothesis}

In the preceding section we reported tests of the hypothesis of equality of the coefficients of earnings functions across geographical markets. We rejected the hypothesis for Panama and therefore accepted a form of the labor market segmentation hypothesis for the country. In the language of Mincer's model, rates of return differ greatly across regions of a very small country. In the language of Tinbergen's model, there is substantial regional variation in the hedonic function for productive characteristics. Such differences may be due to geographical immobility of labor (due to geographical preferences among workers) or may be due to regional variation in the unmeasured quality of the inputs.

A different type of segmentation hypothesis has been advanced in the "dual" 
Table 6

Summary of Mincer Model (Eq.(2)) Estimates (Males, Age 25-64)

\begin{tabular}{|c|c|c|c|c|}
\hline Geographical Region & $\begin{array}{c}\text { Rate of } \\
\text { Return to } \\
\text { Education } \\
\qquad(8)\end{array}$ & $\begin{array}{l}\text { Peak in } \\
\text { Earnings } \\
\text { Profile } \\
\text { (years since } \\
\text { schooling) }\end{array}$ & $\begin{array}{c}\text { Growth Rate } \\
\text { Schooling } \\
\text { Completion } \\
\text { (8) }\end{array}$ & $\begin{array}{l}\text { Earnings } \\
10 \text { Years } \\
\text { After School } \\
(8)\end{array}$ \\
\hline $\begin{array}{l}\text { Entire Country } \\
\text { Bocas } \\
\text { Colon (Excl. Canal Zone) } \\
\text { Colon (Incl. Canal Zone) } \\
\text { Canal Zone } \\
\text { Chiriqui } \\
\text { Cocle } \\
\text { Darien } \\
\text { Herrera } \\
\text { Los Santos } \\
\text { Panama Province } \\
\quad \text { (Excl. Canal Zone) } \\
\text { Panama Province } \\
\quad \text { (Incl. Canal Zone) } \\
\text { Veraguas } \\
\text { U.S. (1959) }\end{array}$ & $\begin{array}{r}12.1 \\
6.0 \\
5.3 \\
4.7 \\
5.3 \\
10.5 \\
11.4 \\
7.5 \\
15.6 \\
13.4 \\
9.3 \\
9.8 \\
14.9 \\
8.2\end{array}$ & $\begin{array}{r}20 \\
34 \\
18 \\
18 \\
28 \\
30 \\
18 \\
9 \\
20 \\
21 \\
\\
26\end{array}$ & $\begin{array}{l}3.8 \\
4.0 \\
4.7 \\
5.0 \\
1.6 \\
2.9 \\
4.1 \\
3.0 \\
3.5 \\
2.4 \\
2.8\end{array}$ & $\begin{array}{c}1.9 \\
2.8 \\
2.1 \\
2.2 \\
1.0 \\
1.9 \\
1.9 \\
-0.03 \\
2.7 \\
1.3 \\
1.7\end{array}$ \\
\hline
\end{tabular}

labor economics literature. According to that literature, the market for low income or marginal workers differs from the market for other workers. This has been interpreted by some to mean that the earnings equation is of a different functional form for "marginal" workers than for others. (See Cain(1976) and the references cited therein).

A superficially attractive way to test this hypothesis in a regression framework divides the data on earnings into two sectors and fits separate earnings equations for the two sectors. Evidence that estimated earnings equations are different in the two sectors appears to suggest that there are in fact two different markets for workers. This empirical strategy is pursued in many. studies of "dual" labor markets (See Cain (1976)).

Table 7 records the result of one such partition of the Panamanian data. 
Dividing workers into a low earnings group--occupled by those at the bottom 25 percentile points of the labor earnings distribution--and the rest, separate earnings equations are fit for each group of workers. Column one records the coefficients of earnings function fit for all workers. Column two reports the coefficients of earnings functions for high income workers while column three reports differences between the earnings functions of low income and high income workers (1.e., low - high). There are clearly sharp differences in the estimated earnings functions for the two sectors, and these differences are statistically significant. By the standards of evidence offered in many analyses of "dualism", Panama has a dual labor market.

In our view, such evidence is not very convincing. First, as noted by Cain (1976), dividing samples on the basis of the dependent variable of a regression analysis and running separate regressions within each subsample can produce sharply biased estimated coefficients. Figure 1 illustrates the point. The solid line in that figure shows a hypothetical population earnings equation based on the simple schooling model of equation (1). The line assumes a positive relationship between income and schooling. The dots around that line represent the residual variability in the earnings equation due to unmeasured variables such as ability and motivation, i.e., the $u$ of equation (1).

Suppose that there is no segmentation of the market in the sense that the solid line represents the mean earnings function for everyone at all levels of schooling. Creating a sample of low earners (people whose earnings are below c) and running regressions on the sample produces a biased estimate of the true regression function. As the level of education increases, the proportion of people in the low income category declines. Those who are in the category tend to have low values of $u$ in equation (1). The measured relationship between income and schooling from samples of low income workers is biased toward zero because the level of $u$ in the sample of low income workers is negatively 
Table 7

Tests of the Dual Labor Market Model*

\begin{tabular}{|c|c|c|c|c|c|c|c|}
\hline Varlable & (1) & (2) & (3) & (4) & (5) & (6) & (7) \\
\hline Constant & $\begin{array}{l}5.589 \\
(.127)\end{array}$ & $\begin{array}{l}6.577 \\
(.1036)\end{array}$ & $\begin{array}{r}-2.28 \\
(.03)\end{array}$ & $\begin{array}{l}.81 \\
(.46)\end{array}$ & $\begin{array}{c}.515 \\
(.043)\end{array}$ & & \\
\hline Ed-Head & $\begin{array}{l}.079 \\
(.006)\end{array}$ & $\begin{array}{l}.0683 \\
(.006)\end{array}$ & $\begin{array}{r}5.32 \\
(1.9)\end{array}$ & $\begin{array}{l}-.21 \\
(.024)\end{array}$ & $\begin{array}{l}. .152 \\
(.002)\end{array}$ & $-2.65 * \star \star$ & $-1.92 * * *$ \\
\hline Age & $\begin{array}{c}.048 \\
(.006)\end{array}$ & $\begin{array}{l}.0318 \\
(.004)\end{array}$ & $\begin{array}{l}-.0007 \\
(.0002)\end{array}$ & $\begin{array}{l}-.035 \\
(.020)\end{array}$ & $\begin{array}{l}-.0052 \\
(.0019)\end{array}$ & -.729 & $-.108 * * *$ \\
\hline AgeSq & $\begin{array}{l}-.0007 \\
(.0001)\end{array}$ & $\begin{array}{l}-.00039 \\
(.00009)\end{array}$ & $\begin{array}{l}-.11145 \\
(.021)\end{array}$ & $\begin{array}{l}.0005 \\
(.0003)\end{array}$ & $\begin{array}{l}.00011 \\
(.00003)\end{array}$ & $-1.66 * * *$ & $-1.43 * * *$ \\
\hline Tralning & $\begin{array}{l}.322 \\
(.04)\end{array}$ & $\begin{array}{l}.186 \\
(.032)\end{array}$ & $\begin{array}{l}.035 \\
(.011)\end{array}$ & $\begin{array}{l}-.8995 \\
(.175)\end{array}$ & $\begin{array}{l}-.0626 \\
(.0136)\end{array}$ & $-2.79 * * *$ & 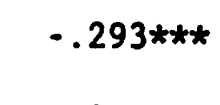 \\
\hline Bocas & $\begin{array}{l}.436 \\
(.083)\end{array}$ & $\begin{array}{c}.135 \\
(.069)\end{array}$ & $\begin{array}{l}1.787 \\
(.86)\end{array}$ & $\begin{array}{r}-1.28 \\
(.39)\end{array}$ & $\begin{array}{l}-.128 \\
(.028)\end{array}$ & $-2.93 * * *$ & $-.242 * * *$ \\
\hline Cocle & $\begin{array}{l}-.458 \\
(.059)\end{array}$ & $\begin{array}{l}-.166 \\
(.065)\end{array}$ & $\begin{array}{l}-.07 \\
(.23)\end{array}$ & $\begin{array}{l}1.07 \\
(.16)\end{array}$ & $\begin{array}{c}.111 \\
(.021)\end{array}$ & $-2.33 * * *$ & $-.278 * * *$ \\
\hline Colon & $\begin{array}{l}.019 \\
(.071)\end{array}$ & $\begin{array}{l}-.062 \\
(.057)\end{array}$ & $\begin{array}{l}.48 \\
(.41)\end{array}$ & $\begin{array}{r}.185 \\
(.28)\end{array}$ & $\begin{array}{l}-.0251 \\
(.0234)\end{array}$ & 9.73 & -1.32 \\
\hline Chiriqui & $\begin{array}{l}-.006 \\
(.052)\end{array}$ & $\begin{array}{l}-.112 \\
(.047)\end{array}$ & $\begin{array}{l}.693 \\
(.227)\end{array}$ & $\begin{array}{l}.466 \\
(.16)\end{array}$ & $\begin{array}{l}.0088 \\
(.0177)\end{array}$ & -77.67 & -1.46 \\
\hline Darien & $\begin{array}{l}-.272 \\
(.124)\end{array}$ & $\begin{array}{l}-.129 \\
(.133)\end{array}$ & $\begin{array}{l}-.253 \\
(.399)\end{array}$ & $\begin{array}{r}.419 \\
(.32)\end{array}$ & $\begin{array}{l}.01965 \\
(.0421)\end{array}$ & $-1.54 * \star *$ & $-.239 * * *$ \\
\hline Herrera & $\begin{array}{l}-.379 \\
(.059)\end{array}$ & $\begin{array}{l}-.184 \\
(.06)\end{array}$ & $\begin{array}{l}.284 \\
(.227)\end{array}$ & $\begin{array}{l}1.29 \\
(.18)\end{array}$ & $\begin{array}{l}.137 \\
(.021)\end{array}$ & $-3.40 * t *$ & $-.361 * * *$ \\
\hline Los Santo & $\begin{array}{l}-.419 \\
(.067)\end{array}$ & -.377 & $\begin{array}{r}.762 \\
(.24)\end{array}$ & $\begin{array}{l}1.27 \\
(.18)\end{array}$ & $\begin{array}{c}.159 \\
(.023)\end{array}$ & $-3.03 * x *$ & $-.379 * \star *$ \\
\hline Veraguas & $\begin{array}{r}-1.003 \\
(.056)\end{array}$ & $\begin{array}{l}-.299 \\
(.08)\end{array}$ & $\begin{array}{r}-.132 \\
(.21)\end{array}$ & $\begin{array}{l}1.98 \\
(.167)\end{array}$ & $\begin{array}{l}.306 \\
(.019)\end{array}$ & $-1.97 * \star \star t$ & $-.305 * * *$ \\
\hline $\begin{array}{l}\text { Canal Zone } \\
\text { Urban }\end{array}$ & $\begin{array}{l}.451 \\
(.090) \\
.552\end{array}$ & $\begin{array}{l}.357 \\
(.066) \\
.1429\end{array}$ & $\begin{array}{l}.426 \\
(.244) \\
.51\end{array}$ & $\begin{array}{r}-1.04 \\
(.74)\end{array}$ & -.0082 & -2.31 & -.018 \\
\hline & & & .51 & -1.34 & -.193 & $-2.43 * * *$ & $-.349 * \star \star *$ \\
\hline
\end{tabular}

Column (1): Population as a Whole

Column (2): Upper Sector (top 758)

Column (3): (Lower Sector - Upper Sector) Difference

Column (4): Logistic Regression ${ }^{* *}$

Column (5): Linear Probability Model

Column (6): Ratio of Col. (4) to Col. (1)

Column (7): Ratio of Col.(5) to Col.(1)

\footnotetext{
*3

The provincial dummies are measured with respect to Panama Province (Panama City and **environs).

*** The dependent variable -1 if person is poor (i.e., in lower 25\%); 0 otherwise. Both coefficients statistically significant
} 
Figure 1

Hypothetical Scatter Diagran and Regression of Earnings on Educational Attainment, with and Without Truncated Earnings

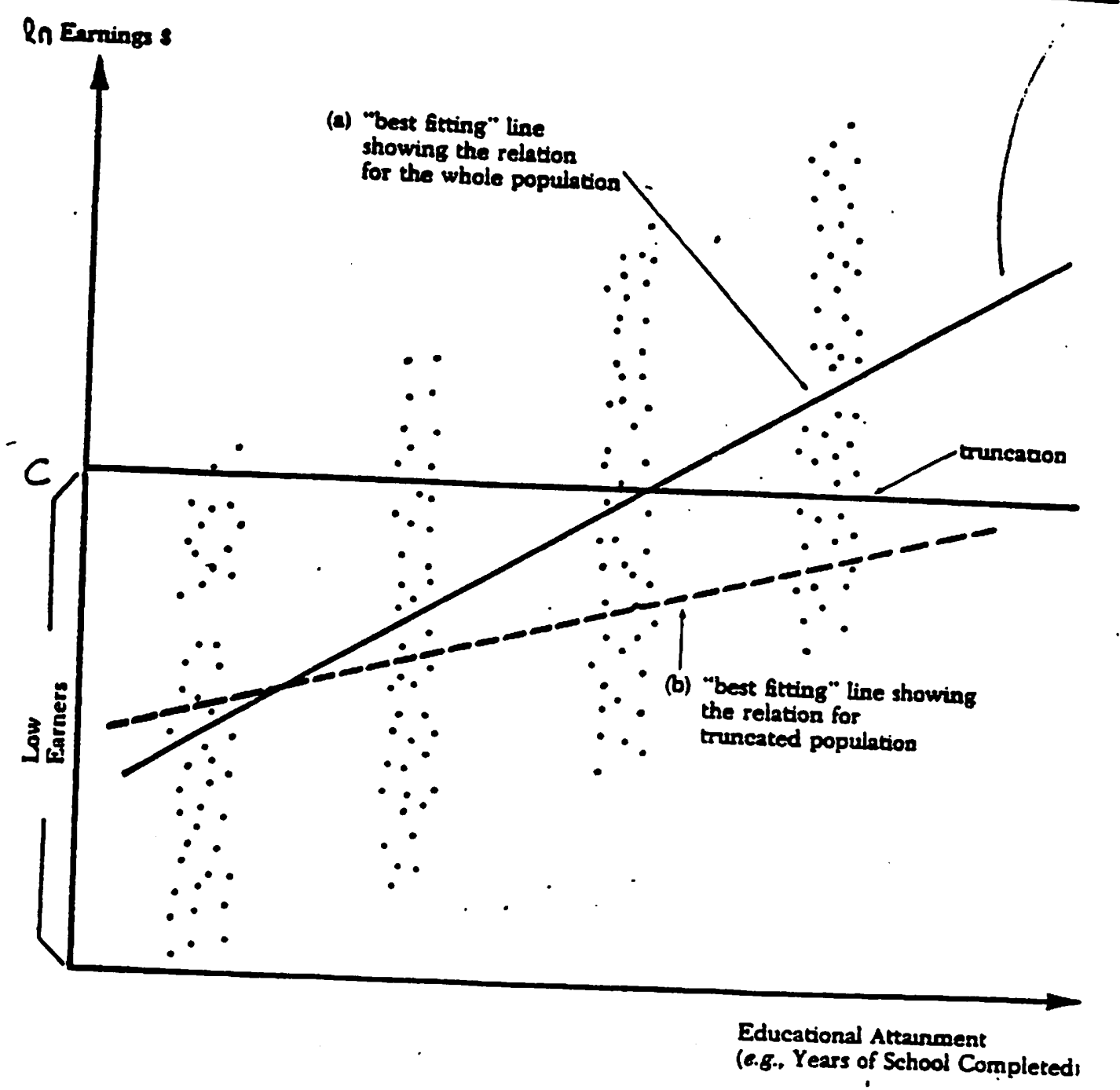

correlated with $s$ even though $u$ is uncorrelated with $s$ in the population. The dashed line in Figure 1 indicates the Impact of this bias on fitted regression equations. Low income workers and high income workers whose behavior is generated by a common regression function (the solid line) appear to be different (the dashed line) only because of the statistical methods used. 
It is possible to correct this bias using sample selection bias techniques developed by Heckman (1976). These methods correct for sample selection by accounting for the effect of income truncation (or other selection rules) on the mean of $u$ in the low income sample. Correcting for sample selection, it is possible to provide a valid test for differences in the coefficients of the earnings function for high income and low income workers.

In the sample selection bias literature it is recognized that equation

describes a hypothetical population and random samples drawn from it. The regression function for the population is:

$$
E(\operatorname{lny} \mid s)-\alpha_{0}+\alpha_{1} s
$$

For a low income population (lny < $c$ where, $c$ is the cut off level) the regression function is:

$$
E(\text { lny } \mid s, \text { lny }<c)-\alpha_{0}+\alpha_{1} s+E(u \mid \operatorname{lny}<c) \text {. }
$$

The final term on the right hand side of equation (4) is the effect of selection on the mean of the unobservables. Omitting the final term from the regression produces biased estimates of $\alpha_{0}$ and $\alpha_{1}$. Using equation (1) it is possible to substitute for lny in the income truncation inequality (lny $<c$ ) to write it as:

$$
u<c-\alpha_{0}-\alpha_{1} s
$$

This inequality restricts the range of unobservable $u$ in the sample in the fashion depicted in Figure 1.

Assuming that the distribution of $u$ is known, it is possible to estimate $E\left(u \mid u<c-\alpha_{0}-\alpha_{1} s\right)$ and insert it as a regressor in the earnings function. Under the null hypothesis that equation (1) is the true population earnings function, it is possible to estimate $\alpha_{0}$ and $\alpha_{1}$ by least squares pooling the data 
from all subpopulations. It is possible to consistently estimate the variance of $u$ from the regression residuals. Assuming that $u$ is normally distributed (or is characterized by any other finite mean two parameter distribution) it is possible to consistently estimate $E(u \mid$ lny $<c)$ for each observation. One test of dual labor market theory partitions the data into high income and low income samples, corrects for sample selection, and then determines whether the estimated coefficients are different in the two subsamples. The test is valid only if (a) the functional form of the population regression function under the null hypothesis of no dualism is known, (b) $u$ is distributed independently of $s^{6}$ and (c) it is possible to consistently estimate the conditional mean of $u$ given selection rule (5). 7

An alternative test of the same hypothesis asks whether or not the earnings function fit for the population as a whole predicts low income status. Under the null hypothesis of no dual labor market, equation (1) characterizes earnings for everyone. The probability that someone is poor should be related to the earnings equation.

The probability that a person is poor given his schooling is

$$
\left.\operatorname{Pr}(\text { lny }<c \mid s)=\operatorname{Pr}\left(u<c-\alpha_{0}-\alpha_{1} s\right) \mid s\right)
$$

Let $F$ be the distribution of $u$ divided by its standard error and let $\sigma_{u}$ be the standard error. Then

6. It is only required that $u$ be uncorrelated with $s$ in order to obtain consistent regression estimators.

7. In applications, this requires specifying the distribution of $u$. Using goodness of fit tests, it is possible to use the least squares residuals from 
$\operatorname{Pr}($ person is poor $\mid s)-F\left(\frac{c-\alpha_{0}-\alpha_{1} s}{\sigma_{u}}\right)$

where we use the fact that division by an arbitrary constant does not change the probability content of inequality (5). Logistic or linear probability model estimates of the probability of low income status should estimate $\alpha_{1} / \sigma_{u}$ assuming that the distribution of $u$ is known to be logistic or uniform respectively. If instead of a single variable, there are many variables that determine earnings, (as in earnings function (2)), the slope coefficients determining earnings should be proportionately related to the slope coefficients of the model determining the probability that someone is in the low income sector. Moreover, the constant of proportionality should be the standard deviation of the earnings function fit over the entire sample of workers. Recent work by Stoker (1984) demonstrates that if the regressors of the model are approximately normally distributed, a linear regression of a dummy variable indicating poverty status (-1 if a person is poor, -0 otherwise) on regressors consistently estimates the coefficients of the probability of poverty up to an unknown factor of proportionality.

Thus, if a common model describes the earnings of all persons, there should be proportionality between the coefficients of earnings equations fit on the entire sample and the coefficients of linear probability models (or logistic models if $u$ is logistically distributed) determining membership in the low income sector. Put another way, if a selection bias corrected earnings function fit on the non-poor is extrapolated to the poor and does not explain their earnings, a dual labor market is said to be present.

Columns 4 and 5 of Table 7 record the regression coefficients of logistic

estimates of (1) to test for any assumed distribution against the data. 
and linear probability regression models in which the dependent variable equals 1 if a person is poor (in the lower 258 of the distribution) and is zero otherwise. These columns produce estimates of the parameters of equation (7) under various assumptions about the distribution of $u$ and the distribution of the regressors. The numbers reported in column (4) are correct if $u$ follows a logistic distribution. The numbers in column (5) are correct if $u$ is uniformly distributed or else the regressors are approximately normally distributed (Stoker (1984)). Columns (6) and (7) record the ratio of the coefficients of Columns (4) and (5) to the coefficients reported in Column (1). Under the null hypothesis of no dual labor market and under the additional hypothesis of correct specification of the logistic or linear probability model, the numbers reported (6) or (7) respectively should be similar. There is a lot of fluctuation even for coefficients which are statistically significant in both the earnings and dummy variable regressions. An eyeball test rejects the hypothesis that the earnings equation and the equation determining participation in low income status are generated by the same model (except for the intercept and constant of proportionality). ${ }^{8}$ By this test, there is dualism in Panama.

In our view, tests of the sort just described are intrinsically unconvincing. Evidence that the coefficients of the equation determining poverty status are not proportional to the coefficients in the earnings equation may simply indicate that earnings are not logistically or uniformly distributed, that the regressors of the earnings equations are not approximately normally distributed, that the earnings equation is misspecified, or all of the above reasons. Evidence of differences in the earnings functions of high income and low income persons produced from sample selection corrected regressions may simply indicate misspecification of the functional form of the "true" earnings

8. A more formal test requires computational facilities and access to data that were not at our disposal. 
function or that the sample selection correction terms have been misspecified, e.g., by imposing an incorrect distributional assumption about $u$. Evidence of similarity in the estimated regression coefficients from such analyses may only be a consequence of misspecifying the "true" cut off line for low income workers, and incorrectly mixing both high income and low income workers into the same category.

At the heart of all of these tests of dual labor market theory--and their central defect--is the assumption that the true functional form of the earnings equation under the hypothesis of no dualism is simple (e.g., a linear or log linear regression). Hedonic models can produce earnings functions that are highly nonlinear in productive attributes. Prices of attributes are determined by supply and demand. Since workers with three years of schooling are not guarantéd to be half as productive as workers with six years of schooling, and Indeed may even perform different tasks in the market, there is no necessarily simple functional relationship between income and education. The same can be said for the relationship between income and any other productive attribute. Since there is no necessarily simple relationship between measured schooling (or work experience) and human capital, similar remarks also apply to human capital earnings models.

If the underlying earnings function is sufficiently nonlinear, dualism will always be found by the tests considered above. Yet there is no necessary economic content in this observation. Such evidence may just indicate the nonlinearity of the pricing equations for attributes characterizing functioning competitive markets. 
7. The Impact of Family Background on Eamings and Educational Attainment

In this section, we examine the importance of family background in determining the economic and educational status of Panamanian males. Table 8 presents evidence on the earnings of Panamanian males age 25-64. These earnings functions differ from the ones analyzed in Section 5 by including the education of the mother and the father as determinants of male earnings. In all specifications of the earnings functions presented, both variables play a powerful. role with the education of the mother playing a larger role than that of the father both in the size of the effect of an additional year of her schooling on her son's earnings and in the statistical precision with which the coefficient on her education is estimated. The mother's education is statistically significant in all specifications while the father's education is sometimes statistically insignificant. An increase in the mother's education by one year raises her son's earnings by 3-58 per annum. The introduction of the background varlables has a tendency to reduce the estimated effects of the son's own education on earnings and the associated rates of return. This evidence indicates that a part of the estimated effect of own education on earnings from regressions that do not control for parental background is due to parental influence on earnings.

We have been unable to find published studies for U.S. data that report results directly comparable to those of Table 8 . Thus we are unable to determine if the estimated effects of family background on earnings are stronger in Panama than in a more mature economy such as the U.S. However, we note that Featherman and Hauser (1978, pp. 293 and 305) find important effects of father's background variables on earnings controlling for some of the same characteristics we use here. In particular, they find that family background variables have an important effect on early earnings but that such effects 
Table 8

Earnings Functions with Fanily Background Variables for the Country as a whole

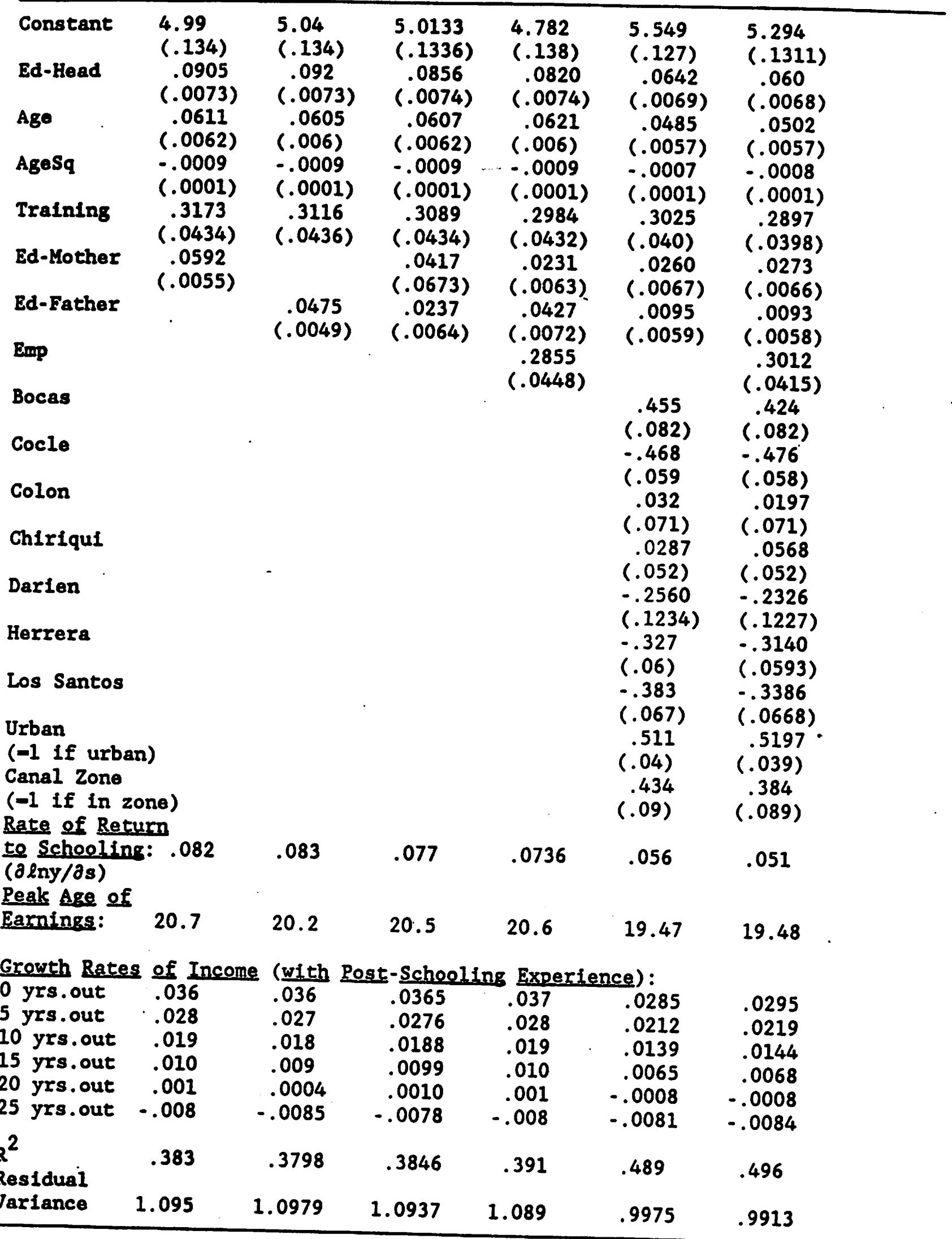


weaken over the life cycle. Leibowitz (1974) presents evidence on the relative importance of mother's education on the earnings of sons that is consistent with what we find here.

The interpretation to be placed on these findings is ambiguous. Radical economists use such evidence to argue that society is stratified along class Iines. Neoclassical economists argue that background variables proxy the quality of the learning environment when the child is young. The fact that the mother's education tends to have a persistently stronger and more robust effect on earnings than the father's education is interpreted as evidence that such beckground variables proxy home quality. Unfortunately, it is not possible to distinguish between these competing hypotheses distinguish between these competing hypotheses with cross section earnings data of the type at our disposal.

We now turn to the question of the influence of familial background on the educational attainment of Panamanian males. Evidence on this questions sheds additional light on the importance of background variables on determining economic status.

Table 9 presents means, standard deviations and intergenerational correlation coefficients for three generations of Panamanians. The data in this table are obtained from households which had at least one son over 18 years of age. Examining the first column of numbers for the country as a whole, note that the educational level of the population has been steadily rising (2.41 for the Grandfather, 4.63 for the Father, and 8.11 for sons). Although the variance or standard deviation of schooling attainment is considerably higher in Panama than in the U.S., there is no discernable trend in either measure of variability. (See Table 1.) Also note that the correlation between the father's education and his father's education (.68) is quite high. The correlation between the father's education and his son's education is lower. 
The observed weakening over time in the intergenerational correlation of educational attainment is consistent with the emergence of state supported educational programs. The correlation between mother's education and son's is much higher than between father's education and son's. This evidence is consistent with the work of Leibowitz (1974) who reports a powerful role of mother's education on son's educational attainment. Such evidence would seem to indicate the importance of the mother in providing a learning environment for her child. It demonstrates a potentially important non-market benefit of mother's education that should be evaluated in assessing the value of subsidies to women's education.

To put these numbers in perspective, we collect comparable results for the U.S. (See Table 10). In 1962, the correlation between father's education and son's is .453 -. substantially lower than the corresponding correlation for Panama. Measured by U.S. standards, there is substantially greater intergenerational correlation in educational attainment in Panama than in the U.S.

Looking at the data in Table 9 disaggregated by province, and breaking out the Canal Zone data for separate treatment (the remaining columns of the Table), the pattern observed for the country as a whole is generally found for each province. The educational attainment correlation for fathers and sons weakens over time, and the correlation between mother's education and son's education is stronger than is the correlation between father's education and son's education. The correlations for the Canal Zone constitute a striking exception to this rule. Note that schooling levels for all generations are substantially higher in the Canal Zone than in other regions of the country, and the variance in the son's educational attainment is much lower.

Table 11 presents univariate and multivariate regression results on intergenerational educational attainment. We present results only for the 
Table 9

Intergenerational Bducational Attaiment in Panamafor the Country as a Whole and by Rogion

\begin{tabular}{|c|c|c|c|c|c|c|}
\hline & \multicolumn{2}{|c|}{ Countery } & \multicolumn{2}{|r|}{ Panaen } & \multicolumn{2}{|c|}{ Colon } \\
\hline & Means & $\begin{array}{l}\text { Seandard } \\
\text { Doviation }\end{array}$ & Means & $\begin{array}{l}\text { Seandard } \\
\text { Doviation }\end{array}$ & Means & $\begin{array}{l}\text { Standard } \\
\text { Doulation }\end{array}$ \\
\hline \multirow{4}{*}{$\begin{array}{l}\text { Grandlathar } \\
\text { Fathor } \\
\text { Son } \\
\text { Mother } \\
\text { Correlatlon } \\
\text { (Grandfathar-Bather) } \\
\text { Correlation } \\
\text { (Father-Son) } \\
\text { Correlation } \\
\text { (Hother-Son) }\end{array}$} & $\begin{array}{l}2.41 \\
4.63 \\
8.11 \\
4.63\end{array}$ & $\begin{array}{l}4.07 \\
4.33 \\
4.36 \\
4.16\end{array}$ & $\begin{array}{r}5.22 \\
7.65 \\
10.76 \\
7.37\end{array}$ & $\begin{array}{l}5.55 \\
5.09 \\
4.11 \\
4.70\end{array}$ & $\begin{array}{l}3.91 \\
6.22 \\
9.22 \\
7.12\end{array}$ & $\begin{array}{l}4.05 \\
3.52 \\
4.41 \\
4.65\end{array}$ \\
\hline & \multicolumn{2}{|c|}{.68} & \multicolumn{2}{|c|}{.65} & \multicolumn{2}{|c|}{.53} \\
\hline & \multicolumn{2}{|c|}{.57} & \multicolumn{2}{|r|}{.54} & \multicolumn{2}{|c|}{.68} \\
\hline & \multicolumn{2}{|c|}{.75} & \multicolumn{2}{|c|}{.71} & \multicolumn{2}{|c|}{.37} \\
\hline
\end{tabular}

\begin{tabular}{|c|c|c|c|c|c|c|}
\hline & \multicolumn{2}{|c|}{ Darion } & \multicolumn{2}{|c|}{ Los Santos } & \multicolumn{2}{|c|}{ Veraguas } \\
\hline & Means & $\begin{array}{l}\text { Standerd } \\
\text { Doviacion }\end{array}$ & Means & $\begin{array}{l}\text { Standard } \\
\text { Deviation }\end{array}$ & Moans & $\begin{array}{l}\text { Seandard } \\
\text { Deviatioa }\end{array}$ \\
\hline \multirow{4}{*}{$\begin{array}{l}\text { Grandfather } \\
\text { Father } \\
\text { Son } \\
\text { Mothor } \\
\text { Correlation } \\
\text { (Grandfather-Father) } \\
\text { Correlation } \\
\text { (Eather-Son) } \\
\text { Correlation } \\
\text { (Mother-Son) }\end{array}$} & $\begin{array}{l}2.60 \\
4.10 \\
5.80 \\
3.29\end{array}$ & $\begin{array}{l}4.05 \\
4.32 \\
3.65 \\
4.32\end{array}$ & $\begin{array}{l}1.09 \\
3.41 \\
7.75 \\
3.71\end{array}$ & $\begin{array}{l}2.37 \\
3.01 \\
3.97 \\
2.71\end{array}$ & $\begin{array}{l}.52 \\
2.45 \\
6.04 \\
2.29\end{array}$ & $\begin{array}{l}1.53 \\
3.01 \\
3.91 \\
3.09\end{array}$ \\
\hline & \multicolumn{2}{|c|}{.73} & \multicolumn{2}{|c|}{.58} & \multicolumn{2}{|c|}{.36} \\
\hline & \multicolumn{2}{|c|}{.12} & \multicolumn{2}{|c|}{.35} & \multicolumn{2}{|c|}{.47} \\
\hline & \multicolumn{2}{|c|}{.21} & \multicolumn{2}{|c|}{.43} & \multicolumn{2}{|c|}{.63} \\
\hline
\end{tabular}

\begin{tabular}{|c|c|c|c|c|c|c|}
\hline & \multicolumn{2}{|c|}{ Herrera } & \multicolumn{2}{|c|}{ Bocas del Toro } & \multicolumn{2}{|c|}{ Cocle } \\
\hline . & Means & $\begin{array}{l}\text { Seandexd } \\
\text { Doviation }\end{array}$ & Means & $\begin{array}{l}\text { Seandard } \\
\text { Deviation }\end{array}$ & Means & $\begin{array}{l}\text { Standard } \\
\text { Deviation }\end{array}$ \\
\hline \multirow{4}{*}{$\begin{array}{l}\text { Grandfather } \\
\text { Fathor } \\
\text { Son } \\
\text { Mother } \\
\text { Correlatlon } \\
\text { (Grandfather-Father) } \\
\text { Correlation } \\
\text { (Father-Son) } \\
\text { Correlation } \\
\text { (Mother-Son) }\end{array}$} & $\begin{array}{l}.85 \\
2.73 \\
6.92 \\
3.06\end{array}$ & $\begin{array}{l}2.68 \\
2.99 \\
4.24 \\
3.11\end{array}$ & $\begin{array}{l}3.3 \\
5.2 \\
8.7 \\
3.9\end{array}$ & $\begin{array}{l}2.54 \\
2.48 \\
3.26 \\
2.11\end{array}$ & $\begin{array}{l}1.85 \\
4.14 \\
7.06 \\
3.99\end{array}$ & $\begin{array}{l}2.63 \\
3.41 \\
3.83 \\
3.03\end{array}$ \\
\hline & \multicolumn{2}{|c|}{.61} & \multicolumn{2}{|c|}{.62} & \multicolumn{2}{|c|}{.5656} \\
\hline & \multicolumn{2}{|c|}{.56} & \multicolumn{2}{|c|}{.63} & \multicolumn{2}{|c|}{.467} \\
\hline & \multicolumn{2}{|c|}{.54} & \multicolumn{2}{|c|}{.801} & \multicolumn{2}{|c|}{.55} \\
\hline
\end{tabular}

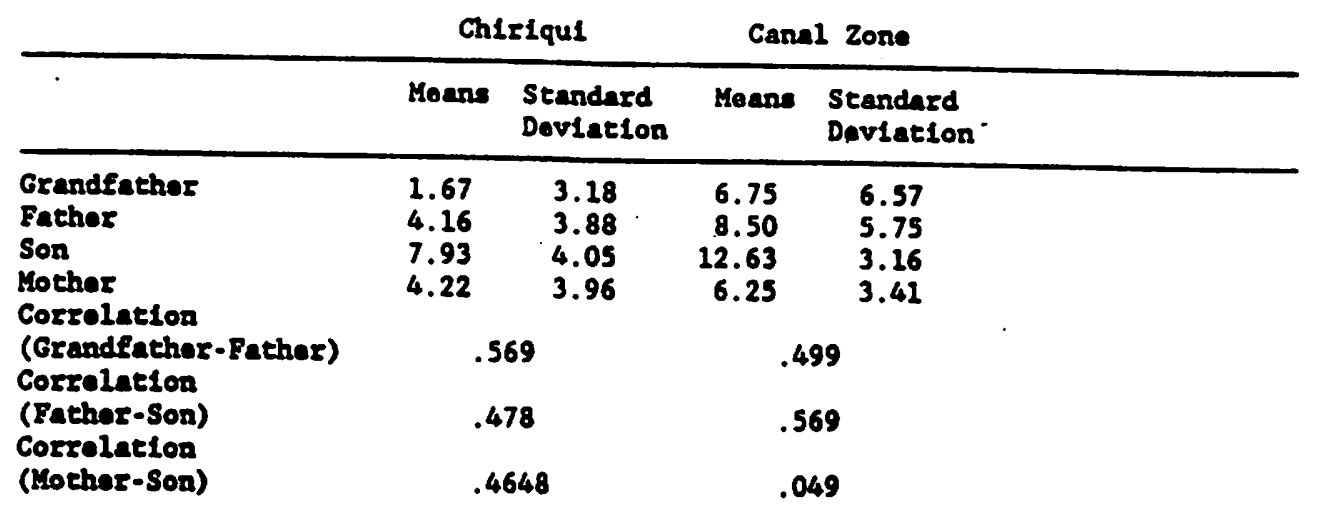


Table 10

Intergenerational Educational Attainment Data From the U.S.

\begin{tabular}{|c|c|c|c|c|}
\hline Country & Year & Correlation & Age Groups & Source \\
\hline $\begin{array}{l}\text { U.S. } \\
\text { U.S. }\end{array}$ & $\begin{array}{l}1962 \\
1962\end{array}$ & $\begin{array}{l}.453 \\
.416 \\
.424 \\
.373 \\
.409\end{array}$ & $\begin{array}{l}\text { All Age groups } \\
\text { Age } 25-34 \\
\text { Age } 35-44 \\
\text { Age } 45-54 \\
\text { Age } 55-64\end{array}$ & $\begin{array}{l}\text { Blau and Duncan }(1967, \text { p. } 169) \\
\text { Blau and Duncan }(1967, \text { p. } 170)\end{array}$ \\
\hline U.S. & 1973 & $\begin{array}{l}.568 \\
\text { (Upper Bound) } \\
.577-.504\end{array}$ & $\begin{array}{l}\text { ALL AGE Groups } \\
\text { For recent groups }\end{array}$ & $\begin{array}{l}\text { Featherman and Hauser } \\
\text { (1978, Pp. 235, 242) } \\
\text { Featherman and Hauser }\end{array}$ \\
\hline d r & e & $\begin{array}{l}\text { re root of } \\
\text { ather's educa } \\
\text { indicating }\end{array}$ & $\begin{array}{l}\text { the } \mathrm{R}^{2} \text { of a regr } \\
\text { tion, mother's educa } \\
\text { whether or not the } s \\
\text { the simple correlat }\end{array}$ & $\begin{array}{l}\text { ression of son's educational } \\
\text { :ation, number of siblings, farm } \\
\text { son grew up in a broken home, } \\
\text { ition between father's education }\end{array}$ \\
\hline
\end{tabular}

country as a whole. The following patterns emerge from this table: (1) The regression coefficients of parental education on son's educational attainment weaken over time, $\underline{1 . e}$, they are weaker for more recent generations than older generations. (2) The effect of father's education and mother's education on son's educational attainment are virtually identical in regressions in which both background variables appear. Both coefficients tend to be smaller for the more recent generation. (3) There are pronounced regional variations in the educational attainments of both the son and the father controlling for background variables. Residents in urban areas have substantially higher educational attainment. This effect is stable over generations. . (4) Holding parental education constant, the education of the paternal grandfather has no effect on the education of his grandson in most specifications of the intergenerational transmission equations (see columns (3)-(5)). However, in one specification, (column (8)), grandfather's education has a negative effect on his grandson's education holding the effects of age, parental education and regional variables constant, although the coefficient is not very precisely 
determined. Assuming that education proxies income, such a negative relationship is predicted by Becker and Tomes (1979, p. 1170) in their theory of Intergenerational income transfers.

\section{SUMMARY}

This paper presents new empirical evidence on the determinants of the earnings of Panamanian males. We reach the following main conclusions. First the estimated rates of return to schooling are high in Panama, especially in the less economically advanced regions of the country. Rates of return are higher In Panama than in the U.S. and other advanced countries but are lower than estimates reported for other Latin American countries. Rates of return to schooling in urban Panama (especially Panama City and the Canal Zone) are comparable with estimates for the U.S. In addition, rates of growth of earnings with experience are lower and earnings functions peak earlier in Panama than in the U.S. This pattern indicates less on-the-job training in Panama than in the U.S. An exception to this pattern occurs in the urban and more advanced sector of the economy.

We find strong regional differences in earnings functions. In the language of Mincer's model, this finding indicates sharp geographical differences in rates of return. In the language of Tinbergen's hedonic model, prices for the same characteristic differ greatly across regions. These differences are surprising in view of the small size of Panama. Labor markets appear to be geographically segmented. There are also strong differences in the functional forms of earnings functions fit for samples of high earnings and low earnings workers. Tests that do not generate spurious differences indicate that earnings functions are not described by a simple functional form. However, there is little behavioral content in this observation. The evidence does not decide the 


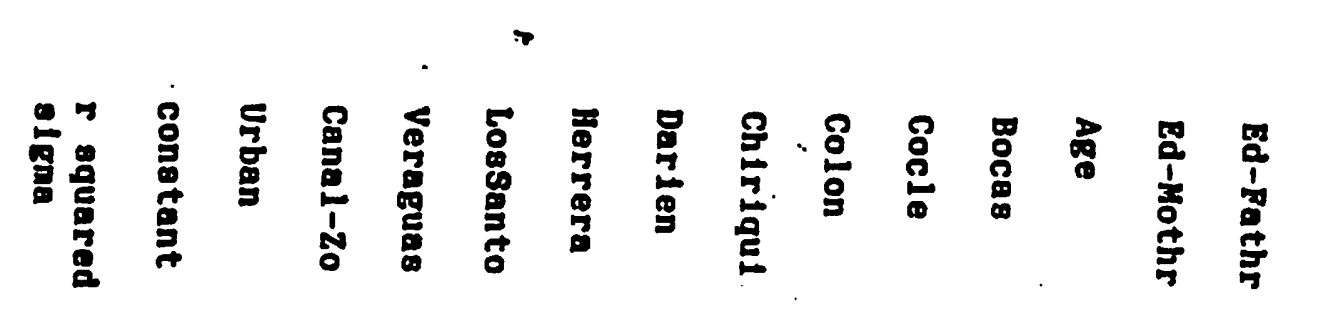
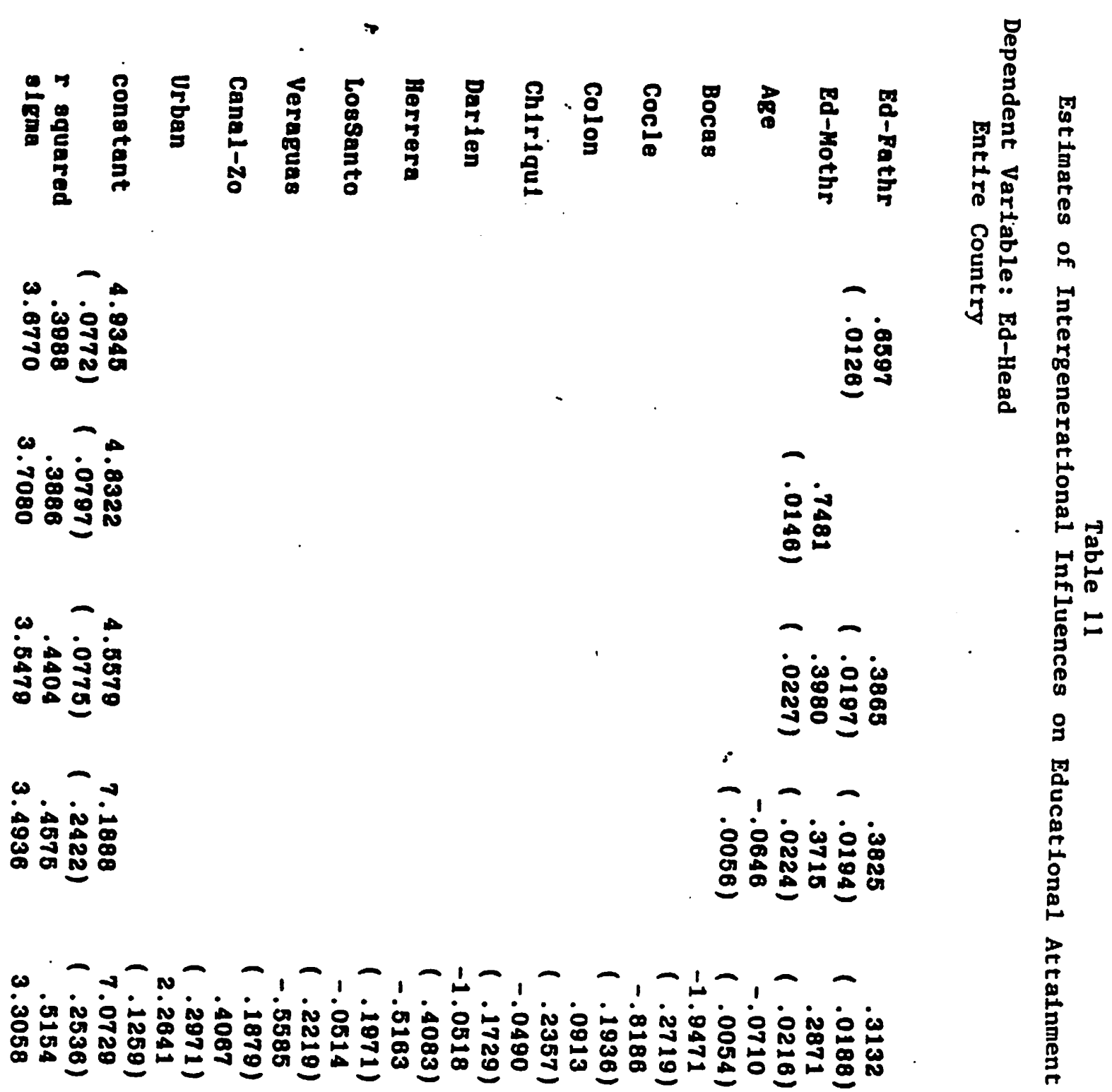


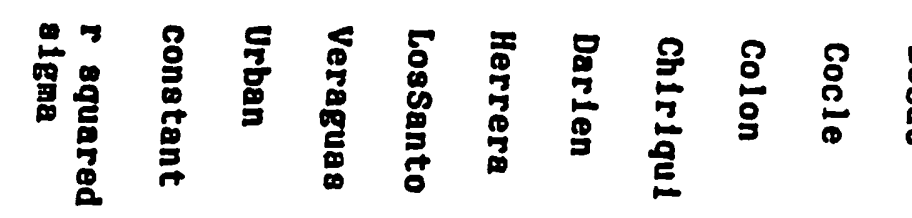
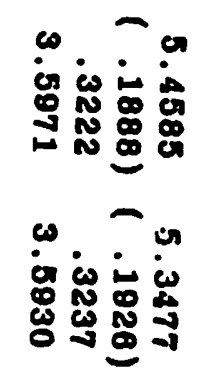

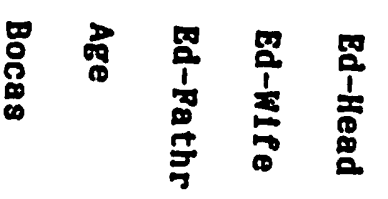
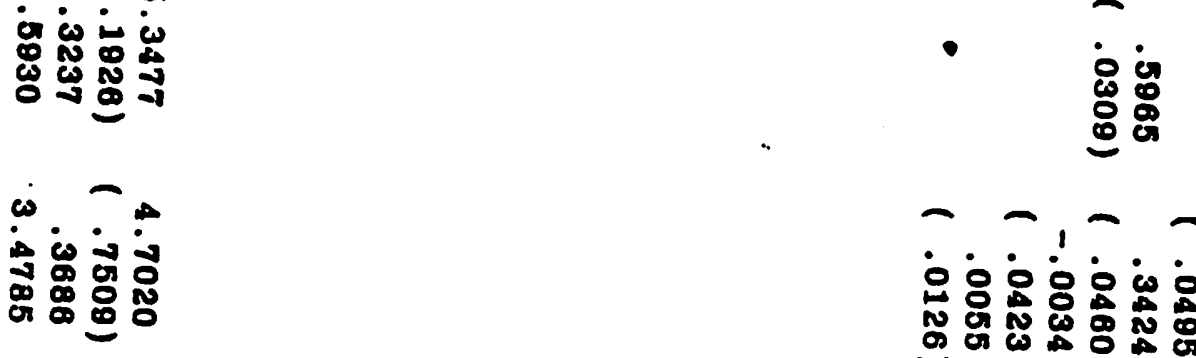

-

용 영

N

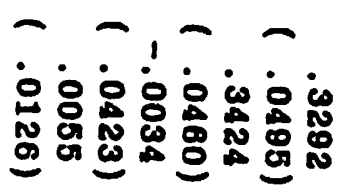

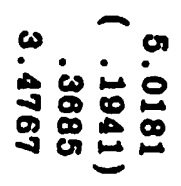
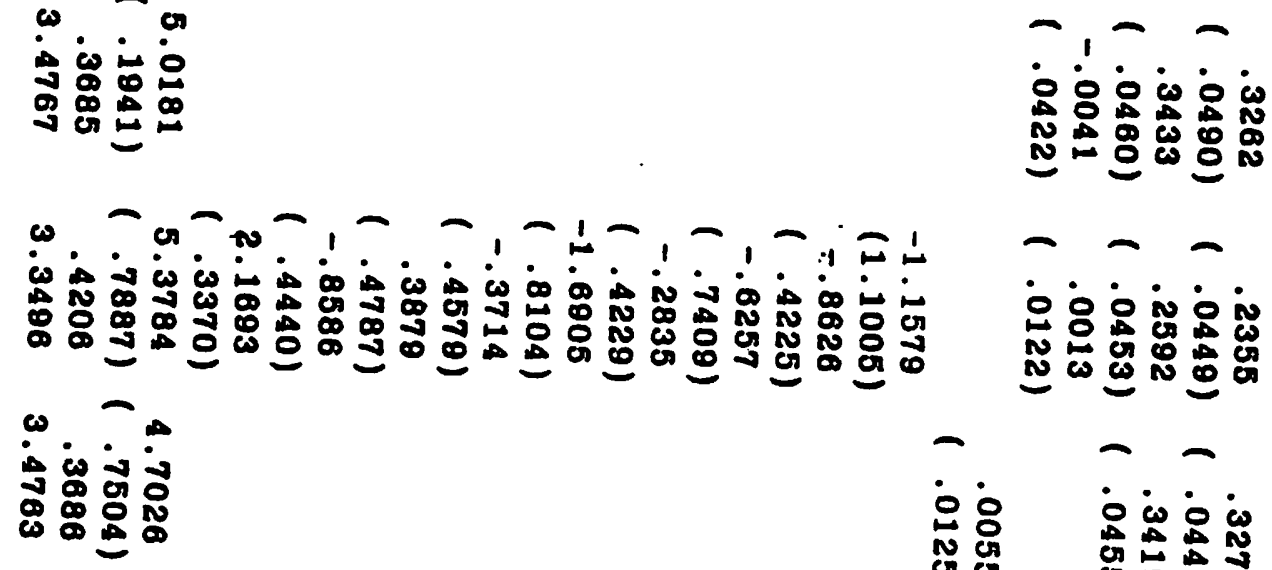

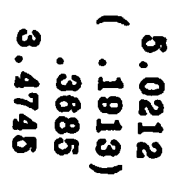
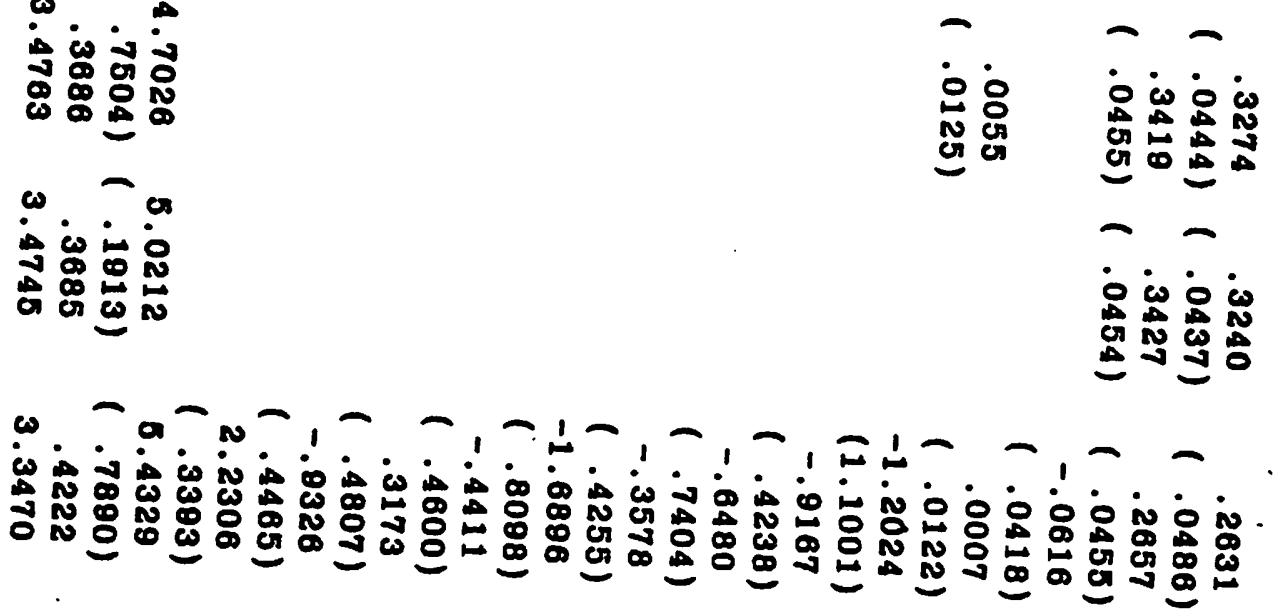
issue of whether or not there are dual labor markets in Panama.

Finally with respect to the impacts of social background, there is a strong effect of parental education and especially mother's education on male earnings. Family background plays an Important role in determining Panamanian male earnings. We also find a strong effect of parental education on the son's educational attainment. While this relationship is weaker for more recent cohorts of Panamanians, it is still much stronger than intergenerational educational attainment relationships found in U.S. data. 


\section{References}

Becker, G., Human Capital, Columbia University Press, 1964 and B. Chiswick, "Education and the Distribution of Earnings", American Economic Review, May 1966.

and N. Tomes, "An Equilibrium Theory of the Distribution of Income and Intergenerational Mobility", Journal of Political Economy, Vol. 87, \#6,

Blau, P. and 0. Duncan, The American Occupational Structure, Wiley, New York, 1967.

Cain, G., "The Challenge of Segmented Labor Market Theories to Orthodox Theory: A Survey", Journal of Economic Literature, Vol.14, \#4, December, 1976, Pp.
1215-1257.

Chiswick, B., Income Inequality, Columbia University Press, 1974.

Feathermian, D. and R. Hauser, Opportunity and Change, Academic Press, New York, 1978.

Griliches, Z., "The Earnings of Very Young Men: A Survey", Journal of Political Economy, Vol. 87, \#5, October, 1979.

Heckman, J., "The Common Structure of Statistical Models of Truncation and Censoring", Annals of Economic and Social Measurement, December, 1976, pp. $492-504$ Leibowitz, A., "Home Investments in Children", Journal of Political Economy,
October 1974.

Mincer, J., "Investments in Human Capital and Personal Income Distribution", Journal of Political Economy, August 1958. , Schooling. Experience and Earnings, Columbia University Press, 1974.

Psacharopoulos, G., "Returns to Education: An Updated International Comparison", Comparative Education, Vol.17, \#3, 1981, pp. 321-341.

Rosen, S., "Hedonic Functions and Implicit Markets", Journal of Political Economy, 1974.

Sattinger, M., Capital and The Distribution of Earnings, North Holland, 1980.

Tinbergen, J., "Some Remarks on the Distribution of Labor Incomes", International Economic Papers, 1, pp. 195-207.

" "On the Theory of Income Distribution", Weltwirshaftliches Archiv, 1956, Vol. 77, 1956, pp. 155-173.

Stoker, T., "The Estimation of Scaled Coefficients", MIT Working Paper, 1984. 
Appendix

Table Al

Estinates for Earnings Function Specifications for Each Region of Panama

BOCAS

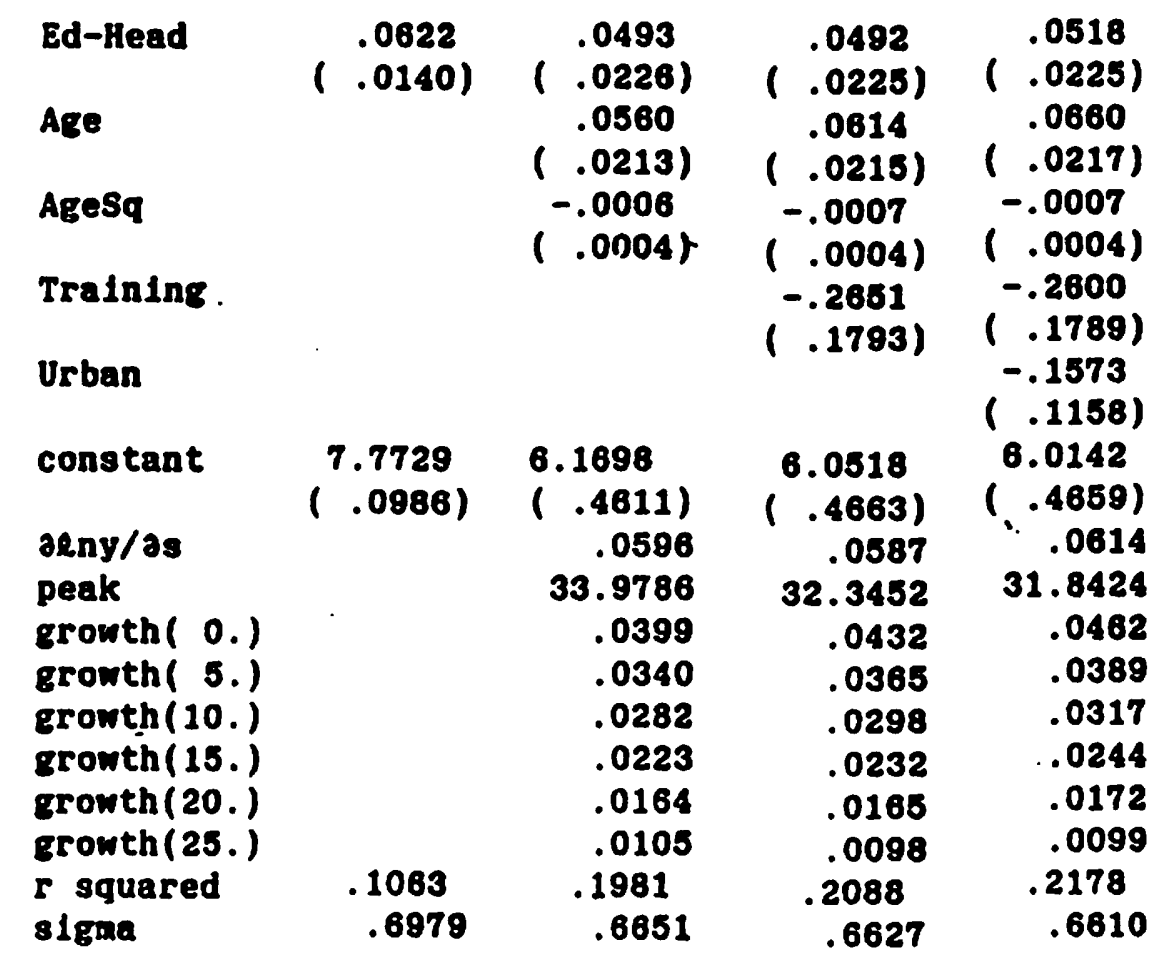


Table AI (continued)

CANAL ZONE

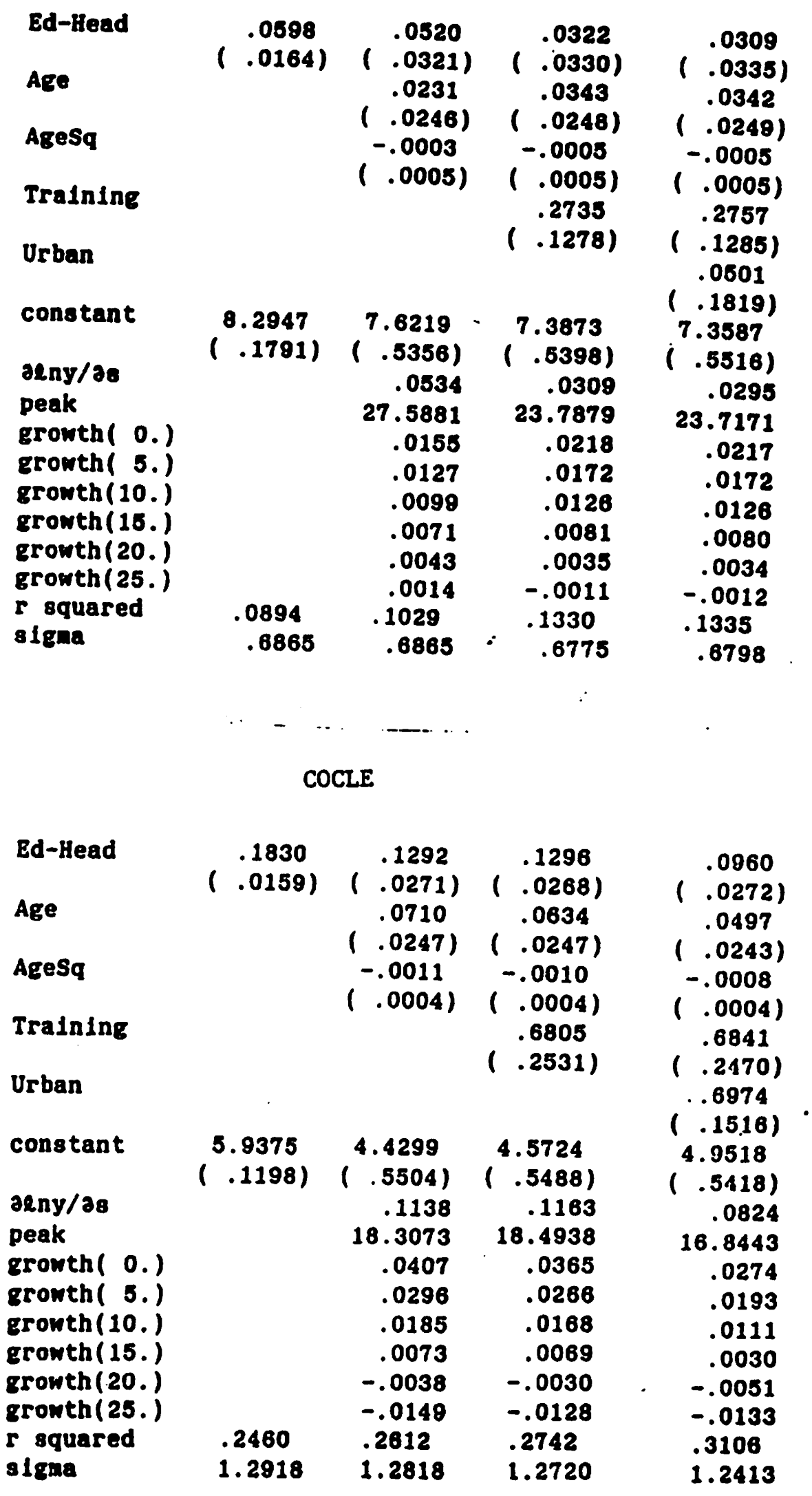


Table Al (continued)

COLON, Including Canal Zone

\begin{tabular}{|c|c|c|c|c|}
\hline Bd-Head & $\begin{array}{l}.1175 \\
(.0158)\end{array}$ & $\left(\begin{array}{l}.0682 \\
.0249)\end{array}\right.$ & $\left(\begin{array}{l}.0674 \\
(.0280)\end{array}\right.$ & $\begin{array}{l}.0438 \\
(.0268)\end{array}$ \\
\hline Age & & $\begin{array}{l}.0865 \\
(.0207)\end{array}$ & $\begin{array}{l}.0885 \\
(.0208)\end{array}$ & $\begin{array}{l}.0903 \\
(.0207)\end{array}$ \\
\hline Agesq & & $\begin{array}{r}-.0014 \\
(.0004)\end{array}$ & $\begin{array}{r}-.0014 \\
(.0004)\end{array}$ & $\left(\begin{array}{r}-.0014 \\
(.0004)\end{array}\right.$ \\
\hline Training & & & $\begin{array}{c}.1438 \\
(.1265)\end{array}$ & $\begin{array}{c}.1376 \\
(.1256)\end{array}$ \\
\hline Urban & & & & $\begin{array}{l}.2582 \\
(.1236)\end{array}$ \\
\hline constant & $\begin{array}{c}7.1146 \\
(.1521)\end{array}$ & $\begin{array}{c}5.1901 \\
(.4401)\end{array}$ & $\begin{array}{c}5.1729 \\
(.4401)\end{array}$ & $\begin{array}{r}5.0969 \\
(\quad .4383)\end{array}$ \\
\hline $\begin{array}{l}\text { alny/as } \\
\text { peak }\end{array}$ & & $\begin{array}{r}.0473 \\
18.2786\end{array}$ & $\begin{array}{r}.0367 \\
17.8729\end{array}$ & $\begin{array}{r}.0215 \\
17.5474\end{array}$ \\
\hline Erowth $(0)$. & & .0495 & .0501 & .0508 \\
\hline growth( 5.) & & .0360 & .0361 & .0363 \\
\hline growth (10.) & & .0224 & .0221 & .0218 \\
\hline growth (15.) & & .0089 & .0081 & .0074 \\
\hline growth (20.) & & -.0047 & -.0060 & -.0071 \\
\hline growth (25.) & 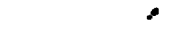 & -.0182 & -.0200 & -.0216 \\
\hline $\begin{array}{l}\text { squared } \\
\text { slema }\end{array}$ & $\begin{array}{r}.1952 \\
.9018\end{array}$ & $\begin{array}{r}.2649 \\
.8656\end{array}$ & $\begin{array}{l}.2691 \\
.8650\end{array}$ & $\begin{array}{r}.2830 \\
.8586\end{array}$ \\
\hline
\end{tabular}

COLON, Excluding Canal Zone

\begin{tabular}{|c|c|c|c|c|}
\hline Ed-Heed & $\left(\begin{array}{l}.1214 \\
(.0170)\end{array}\right.$ & $\begin{array}{l}.0716 \\
(.0268)\end{array}$ & $\left(\begin{array}{l}.0631 \\
(.0281)\end{array}\right.$ & $\begin{array}{l}.0505 \\
(.0288)\end{array}$ \\
\hline Age & & $\begin{array}{l}.0829 \\
(.0228)\end{array}$ & $\begin{array}{l}.0842 \\
(.0229)\end{array}$ & $\begin{array}{l}.0856 \\
(.0227)\end{array}$ \\
\hline AgeSq & & $\left(\begin{array}{c}-.0013 \\
(.0004)\end{array}\right.$ & $\begin{array}{c}-.0013 \\
(.0004)\end{array}$ & $\begin{array}{c}-.0014 \\
(.0004)\end{array}$ \\
\hline Tralning & & & $\begin{array}{l}.1465 \\
(.1413)\end{array}$ & $\begin{array}{l}.1385 \\
(.1405)\end{array}$ \\
\hline Urban & & & & $\begin{array}{l}.2472 \\
(.1374)\end{array}$ \\
\hline constant & $\begin{array}{l}7.0005 \\
(.1624)\end{array}$ & $\begin{array}{c}5.1841 \\
(.4828)\end{array}$ & $\begin{array}{c}5.1813 \\
(.4827)\end{array}$ & $\begin{array}{c}5.1168 \\
(.4813)\end{array}$ \\
\hline $\begin{array}{l}\text { alny/as } \\
\text { peak }\end{array}$ & & $\begin{array}{r}.0526 \\
17.9587\end{array}$ & $\begin{array}{r}.0422 \\
17.5261\end{array}$ & .0290 \\
\hline growth $(0)$. & & .0471 & .0473 & $\begin{array}{r}17.4155 \\
.0480\end{array}$ \\
\hline $\begin{array}{l}\text { Erowth }(5 .) \\
\text { growth }(10 .)\end{array}$ & & $\begin{array}{l}.0340 \\
.0209\end{array}$ & $\begin{array}{l}.0338 \\
.0203\end{array}$ & $\begin{array}{l}.0342 \\
.0204\end{array}$ \\
\hline growth(15.) & & .0078 & .0068 & .0067 \\
\hline $\begin{array}{l}\text { growth (20.) } \\
\text { growth (25.) }\end{array}$ & & $\begin{array}{l}-.0054 \\
-.0185\end{array}$ & $\begin{array}{l}-.0087 \\
-.0202\end{array}$ & $\begin{array}{l}-.0071 \\
-.0209\end{array}$ \\
\hline $\begin{array}{l}r \text { squared } \\
\text { sigaa }\end{array}$ & $\begin{array}{l}.2078 \\
.9210\end{array}$ & $\begin{array}{c}.2679 \\
.8899\end{array}$ & $\begin{array}{r}.2720 \\
.8897\end{array}$ & $\begin{array}{r}.2841 \\
.8846\end{array}$ \\
\hline
\end{tabular}


Table AI (continued)

\section{CHIRIQUE}

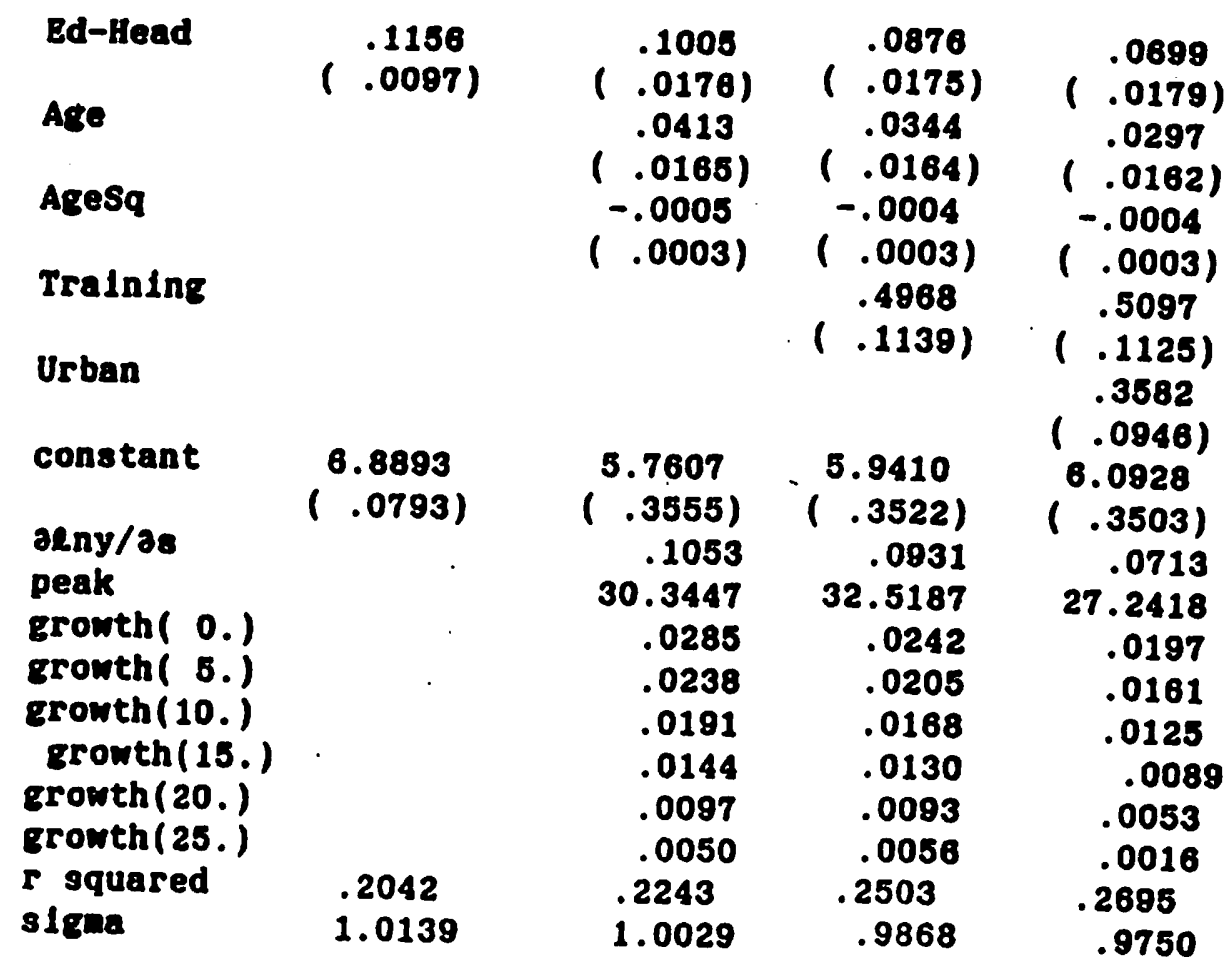

DARIEN

\begin{tabular}{|c|c|c|c|c|}
\hline Ed-llead & $\left(\begin{array}{l}.2257 \\
.0386)\end{array}\right.$ & $\begin{array}{l}.1289 \\
(.0644)\end{array}$ & $\left(\begin{array}{l}.1548 \\
.0707)\end{array}\right.$ & $\begin{array}{l}.1545 \\
(.0712)\end{array}$ \\
\hline Age & & $\left(\begin{array}{l}.0752 \\
(.0803)\end{array}\right.$ & $\begin{array}{l}.0796 \\
(.0606)\end{array}$ & $\begin{array}{l}.0723 \\
(.0646)\end{array}$ \\
\hline AgeSq & & $\left(\begin{array}{c}-.0017 \\
(.0010)\end{array}\right.$ & $\begin{array}{l}-.0017 \\
(.0010)\end{array}$ & $\begin{array}{c}-.0016 \\
(.0011)\end{array}$ \\
\hline Traln1ng & & & $\begin{array}{r}-.3990 \\
(.4463)\end{array}$ & $\begin{array}{c}-.4040 \\
(.4495)\end{array}$ \\
\hline roan & & & & $\left(\begin{array}{l}.1530 \\
.4459)\end{array}\right.$ \\
\hline constant & $\begin{array}{c}5.9234 \\
(.2572)\end{array}$ & $\begin{array}{c}5.0301 \\
(1.2602)\end{array}$ & $\begin{array}{c}4.8707 \\
(1.2746)\end{array}$ & $\begin{array}{c}5.0294 \\
(1.3641)\end{array}$ \\
\hline $\begin{array}{l}\text { arny/as } \\
\text { peak }\end{array}$ & & $\begin{array}{r}.0750 \\
8.9997\end{array}$ & $\begin{array}{r}.1020 \\
9.7258\end{array}$ & $\begin{array}{r}.1027 \\
8.9893\end{array}$ \\
\hline Erowth ( 0.) & & .0299 & .0331 & .0287 \\
\hline Erowth (5.) & & .0133 & .0161 & .0127 \\
\hline growth (10.) & & -.0033 & -.0009 & -.0032 \\
\hline Erowth (15.) & & -.0199 & -.0179 & -.0192 \\
\hline rowth (20.) & & -.0365 & -.0350 & -.0351 \\
\hline erowth (25.) & & -.0531 & -.0520 & -.0511 \\
\hline $\begin{array}{l}\text { squared } \\
\text { slgaa }\end{array}$ & $\begin{array}{l}.3307 \\
1.3242\end{array}$ & $\begin{array}{l}.3718 \\
1.3019\end{array}$ & $\begin{array}{l}.3794 \\
1.3038\end{array}$ & $\begin{array}{l}.3805 \\
1.3126\end{array}$ \\
\hline
\end{tabular}


Table Al (continued)

HERRERA

\begin{tabular}{|c|c|c|c|c|}
\hline Ed-Head & $\begin{array}{l}.2048 \\
(.0122)\end{array}$ & $\begin{array}{l}.1683 \\
.0225\end{array}$ & $\begin{array}{l}.1461 \\
.0225)\end{array}$ & $\begin{array}{l}.0925 \\
(.0217)\end{array}$ \\
\hline Age & & $\begin{array}{l}.0594 \\
(.0212)\end{array}$ & $\begin{array}{l}.0475 \\
(.0210)\end{array}$ & $\begin{array}{l}.0526 \\
(.0193)\end{array}$ \\
\hline AgeSq & & $\begin{array}{c}-.0009 \\
\left(\begin{array}{c}.0004\end{array}\right)\end{array}$ & $\left(\begin{array}{c}-.0007 \\
(.0004)\end{array}\right.$ & $\left(\begin{array}{c}-.0008 \\
(.0003)\end{array}\right.$ \\
\hline Iraining & & & $\begin{array}{l}.5616 \\
(.1326)\end{array}$ & $\begin{array}{c}.4352 \\
(.1232)\end{array}$ \\
\hline Urban & & & & $\begin{array}{l}.9262 \\
(.1137)\end{array}$ \\
\hline constant & $\begin{array}{c}6.0359 \\
(\quad .0969)\end{array}$ & $\begin{array}{c}4.7174 \\
(\quad .4527)\end{array}$ & $\begin{array}{c}5.0142 \\
(.4482)\end{array}$ & $\begin{array}{c}4.7821 \\
(.4140)\end{array}$ \\
\hline $\begin{array}{l}\text { alny/as } \\
\text { peak }\end{array}$ & & $\begin{array}{r}.1562 \\
20.0863\end{array}$ & $\begin{array}{r}.1377 \\
19.4240\end{array}$ & $\begin{array}{r}.0797 \\
17.6427\end{array}$ \\
\hline Erowth ( 0.) & & .0353 & .0279 & $\begin{array}{l}.0296 \\
.0212\end{array}$ \\
\hline $\begin{array}{l}\text { growth ( 6.) } \\
\text { erowth (10.) }\end{array}$ & & $\begin{array}{l}.0265 \\
.0177\end{array}$ & $\begin{array}{l}.0207 \\
.0135\end{array}$ & $\begin{array}{l}.0212 \\
.0128\end{array}$ \\
\hline growth (15.) & & .0090 & .0064 & .0044 \\
\hline Erowth (20.) & & .0002 & $\begin{array}{r}-.0008 \\
-.0080\end{array}$ & $\begin{array}{r}-.0040 \\
-.0124\end{array}$ \\
\hline $\begin{array}{l}\text { Erowth(25.) } \\
\text { s squared }\end{array}$ & & -.0086 & $\begin{array}{l}-.0080 \\
.4716\end{array}$ & .5525 \\
\hline sigma & 1.0421 & 1.0326 & 1.0097 & .9304 \\
\hline
\end{tabular}

LOS SANTOS

\begin{tabular}{|c|c|c|c|c|}
\hline Ed-Heed & .1596 & .1386 & .0959 & .0809 \\
\hline & & $(.0282)$ & $(.0310)$ & $(.0317)$ \\
\hline Age & & .0387 & $\cdot 0379$ & .0354 \\
\hline & & $(.0263)$ & $(.0260)$ & $(.0259)$ \\
\hline AgeSq & & -.0008 & -.0008 & $\div .0006$ \\
\hline & & $(.0004)$ & $(.0004)$ & $(.0004)$ \\
\hline Tralning & & & & .6246 \\
\hline Urban & & & & (.2183) \\
\hline (2) dan & & & .6829 & .4089 \\
\hline constant & & & (.2175) & (.2009) \\
\hline 20 & $\begin{array}{c}6.0781 \\
(.1227)\end{array}$ & $\begin{array}{r}5.1735 \\
(.5896)\end{array}$ & 5.3895 & 5.5219 \\
\hline alny/28 & & .1345 & $\begin{array}{r}(.5852) \\
.0882\end{array}$ & (. .5858) \\
\hline peak & & 21.4839 & $\begin{array}{r}.0862 \\
17.3087\end{array}$ & .0682 \\
\hline Erowth $(0)$. & & .0236 & $\begin{array}{r}17.3087 \\
.0212\end{array}$ & 14.9228 \\
\hline Erowth (5.) & & .0181 & $\begin{array}{l}.0212 \\
.0151\end{array}$ & .0185 \\
\hline growth (10.) & & .0126 & $\begin{array}{l}.0151 \\
.0089\end{array}$ & .0123 \\
\hline Erowth(15.) & & & $\begin{array}{l}.0089 \\
.0028\end{array}$ & .0061 \\
\hline growth(20.) & & & $\begin{array}{r}.0028 \\
-.0033\end{array}$ &.-0001 \\
\hline growth (25.) & & $\begin{array}{r}.0010 \\
-.0039\end{array}$ & $\begin{array}{l}-.0033 \\
-.0094\end{array}$ & -.0083 \\
\hline squared & .2163 & .2226 & $\begin{array}{l}-.0094 \\
.2473\end{array}$ & -.0125 \\
\hline sigara & 1.2184 & 1.2174 & $\begin{array}{l}.2473 \\
1.2000\end{array}$ & $\begin{array}{l}.2075 \\
1.1937\end{array}$ \\
\hline
\end{tabular}


Table Al (continued)

PANAMA PROVINCE, Including Canal zone

\begin{tabular}{|c|c|c|c|c|}
\hline Bd-Head & .1107 & .0837 & .0883 & .0789 \\
\hline Age & & .0418 & $\begin{array}{l}(.0085) \\
-.0401\end{array}$ & $\begin{array}{c}(.0084) \\
.0348\end{array}$ \\
\hline Agesq & & $\begin{array}{c}(.0075) \\
-.0005 \\
(.0001)\end{array}$ & $\begin{array}{c}(.0074) \\
-.0005 \\
(.0001)\end{array}$ & $\begin{array}{c}(.0073) \\
-.0004 \\
(.0001)\end{array}$ \\
\hline Training & & & $\left(\begin{array}{l}.2020 \\
(.0468)\end{array}\right.$ & $\begin{array}{l}.1923 \\
(.0458) \\
.4661 \\
(.0550)\end{array}$ \\
\hline constant & $\begin{array}{l}7.2253 \\
(.0498)\end{array}$ & $\begin{array}{c}6.1002 \\
(.1553)\end{array}$ & $\begin{array}{l}6.1377 \\
(.1547)\end{array}$ & $\begin{array}{c}6.0014 \\
(.1521)\end{array}$ \\
\hline $\begin{array}{l}\text { alny/3a } \\
\text { peak }\end{array}$ & & $\begin{array}{r}.0979 \\
29.5135\end{array}$ & $\begin{array}{r}.0929 \\
30.3008\end{array}$ & $\begin{array}{r}.0848 \\
33.1834\end{array}$ \\
\hline $\begin{array}{l}\text { Erowth( 0.) } \\
\text { erowth }(5 .)\end{array}$ & & $\begin{array}{r}.0286 \\
.0238\end{array}$ & $\begin{array}{l}.0278 \\
.0231\end{array}$ & $\begin{array}{l}.0247 \\
.0209\end{array}$ \\
\hline growth (10.) & & .0189 & .0185 & .0172 \\
\hline $\begin{array}{l}\operatorname{growth}(15 .) \\
\operatorname{growth}(20 .)\end{array}$ & & .0141 & .0139 & .0135 \\
\hline growth (25.) & & $\begin{array}{l}.0092 \\
.0044\end{array}$ & $\begin{array}{l}.0094 \\
.0048\end{array}$ & $\begin{array}{l}.0098 \\
.0061\end{array}$ \\
\hline $\begin{array}{l}\text { r squared } \\
\text { s lgma }\end{array}$ & $\begin{array}{l}.2863 \\
.8417\end{array}$ & $\begin{array}{c}.2992 \\
.8231\end{array}$ & $\begin{array}{c}.3074 \\
.8185\end{array}$ & $\begin{array}{l}.3378 \\
.8006\end{array}$ \\
\hline
\end{tabular}

PANAMA PROVINCE, Excluding Canal Zone

\begin{tabular}{|c|c|c|c|c|}
\hline Ed-Head & $\left(\begin{array}{l}.1114 \\
.0047)\end{array}\right.$ & $\left(\begin{array}{l}.0916 \\
(.0085)\end{array}\right.$ & $\begin{array}{l}.0868 \\
(.0086)\end{array}$ & $\left(\begin{array}{l}.0776 \\
(.0085)\end{array}\right.$ \\
\hline Age & & $\begin{array}{l}.0418 \\
(.0076)\end{array}$ & $\begin{array}{l}.0398 \\
(.0076)\end{array}$ & $\begin{array}{l}.0350 \\
(.0075)\end{array}$ \\
\hline AgreSq & & $\begin{array}{l}-.0005 \\
(.0001)\end{array}$ & $\begin{array}{c}-.0005 \\
-(.0001)\end{array}$ & $\begin{array}{c}-.0004 \\
(.0001)\end{array}$ \\
\hline Tralndng & & & $\begin{array}{l}.1862 \\
(.0485)\end{array}$ & $\begin{array}{l}.1742 \\
(.0474)\end{array}$ \\
\hline Urban & & & & $\begin{array}{l}.4546 \\
(.0557)\end{array}$ \\
\hline constant & $\begin{array}{l}7.1768 \\
(.0503)\end{array}$ & $\begin{array}{c}6.1108 \\
(.1587)\end{array}$ & $\begin{array}{c}6.1533 \\
(.1583)\end{array}$ & $\begin{array}{c}6.0154 \\
(.1558)\end{array}$ \\
\hline $\begin{array}{l}\text { alny/as } \\
\text { peak }\end{array}$ & & $\begin{array}{r}.0925 \\
26.1053\end{array}$ & $\begin{array}{r}.0883 \\
26.6884\end{array}$ & $\begin{array}{r}.0803 \\
28.4125\end{array}$ \\
\hline growth $(0)$. & & .0275 & .0263 & .0236 \\
\hline Erowth (5.) & & .0222 & .0214 & .0195 \\
\hline growth (10.) & & .0169 & .0165 & .0153 \\
\hline growth (15.) & & .0117 & .0115 & .0112 \\
\hline Erowth (20.) & & .0064 & .0066 & .0070 \\
\hline growth (26.) & & .0012 & .0017 & .0028 \\
\hline $\begin{array}{l}\text { s squared } \\
\text { slgaa }\end{array}$ & $\begin{array}{l}.2765 \\
.8338\end{array}$ & $\begin{array}{r}.3042 \\
.8183\end{array}$ & $\begin{array}{r}.3111 \\
.8144\end{array}$ & $\begin{array}{l}.3411 \\
.7968\end{array}$ \\
\hline
\end{tabular}


Table Al (continued)

VERAGUAS

\begin{tabular}{|c|c|c|c|c|}
\hline Bd-Head & $\begin{array}{l}.2276 \\
(.0123)\end{array}$ & .1669 & .1423 & .0910 \\
\hline Age & & $\begin{array}{c}.0208 \\
.0902\end{array}$ & $\begin{array}{l}.0217) \\
.0818\end{array}$ & $\begin{array}{c}(.0223) \\
.0640\end{array}$ \\
\hline & & $(.0218)$ & $(.0218)$ & $(.0211)$ \\
\hline Agesq & & -.0014 & -.0013 & -.0011 \\
\hline rraining & & $(.0004)$ & $(.0004)$ & $(.0003)$ \\
\hline raduinte & & & .6413 & .6770 \\
\hline Urban & & & $(.1819)$ & $\begin{array}{c}.1748) \\
1.0264\end{array}$ \\
\hline onstant & & & & $(.1605)$ \\
\hline 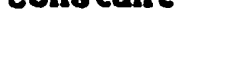 & $(.0899)$ & $\begin{array}{r}3.2555 \\
(.4927)\end{array}$ & $\begin{array}{r}3.5377 \\
(.4934)\end{array}$ & 4.0400 \\
\hline alny/as & & .1485 & $\begin{array}{r}.00014 \\
.1214\end{array}$ & $(.4801)$ \\
\hline peak & & 18.6348 & 17.3417 & .0687 \\
\hline Erowth $(0)$. & & .0521 & .0457 & 15.1931 \\
\hline growth (5.) & & .0381 & .0326 & .0337 \\
\hline growth(10.) & & .0241 & .0194 & .0226 \\
\hline Erowth(15.) & & 0102 & .0194 & .0115 \\
\hline growth (20.) & & $.010 a$ & $\begin{array}{r}.0082 \\
-.0070\end{array}$ & .0004 \\
\hline growth (25.) & & -.0038 & -.0070 & -.0107 \\
\hline I squared & .4215 & .4416 & $\begin{array}{l}-.0202 \\
.4560\end{array}$ & -.0218 \\
\hline slema & 1.3033 & 1.2831 & 1.2678 & $\begin{array}{l}.4996 \\
1.2172\end{array}$ \\
\hline
\end{tabular}


$8101 C$

$8102 C$.

$8103 \mathrm{C}$

$8104 C$

$8105 \mathrm{C}$

$8106 C$

$8107 C$

8108C D gJ

8109C D S

$8110 \mathrm{C}$

$8111 \mathrm{C}$

$8201 C$

$820 \dot{2 C}$

$8203 \mathrm{C}$

$8204 \mathrm{C}$

$8205 C$

$8206 C$

$8207 \mathrm{C}$

$8208 \mathrm{C}$

8209C DSU

Markusen, James R. Factor Movements and Commodity Trade as Compliments: A Survey of some Cases.

Conlon, R.M. Comparison of Australian and Canadian Manufacturing Industries: Some Empirical Evidence.

Conlon, R.M. The Incidence of Transport cost and Tariff protection: Some Australian Evidence.

Laidler, David. On the Case for Gradualism.

Wirick, Ronald G. Rational Expectations and Rational Stabilization Policy in an Open Economy

Mansur, Ahsan and John Whalley Numerical secification of Applied General Equilibrium Models: Estimation, Calibration, and Data.

Burgess, David F., Energy Prices, Capital Formation, and Potential GNP Jimenez, B. and Douglas $\mathrm{H}$ Keare. Kousing Consumption and Income in the Low Income Urban stting: Estimates from Panel Data in El silvador Whalley, John Labour Migration and the North-South Debate' Manning, Richard and John McMillan Government Expenditure and Comparative Advantage

Freid, Joel and Peter why Inflation Reduces Real I hterest Rates

\section{$\underline{1982}$}

Manning, Richard and James R. Markusen Dynamic Non- Sbstitution and Long Run Production Possibilities

Feenstra, Robert and Ken Judd Tariffs, Technology Transfer, and Welfare

Ronald W. Jones, and Douglas D. Purvis: International Differences in Response to Common External Shocks: The Role of Purchasing Power Parity

James A Brander and Barbara J. \$pencer: Industrial strategy with Committed Firms

Whalley, John, The North-South Debate and the Terms of Trade: An Applied General Equilibrium Approach

Roger Betancourt, Christopher Clague, Arvind Panagariya CAPI TAL UTILI ZATI ON IN GENERAL EQUIITBRTUM

Mansur, Ahsan $H$ On the Estimation of Import and Export Demand Elasticities and Elasticity Pessimism.

Whalley, J. and Randy Wigle PRICE AND QUANTITY RIGIDITIES IN ADJUSTMENT TO TRADE POLICY CHANGES: ALTERNATIVE FORMULATIONS AND INITIAL CALCULATIONS JImenez, E. SQUATTING AND COMMUNITY ORGANIZATION IN DEVELOPING COUNTRIES:
A CONCEPTUAL FRAMEWORK 
$8210 C$ Grossman, G.M. INTERNATIONAL COMPETITION AND THE UNIONIZED SECTOR

8211C LaIdler,D. ERIEDMAN AND SCHHARTZ ON MONETARY IRENDS - A REVIEW ARTICLE

8212C . Imam, M.H: and Whalley, J. INCIDENCE ANALYSIS OP A SECTOR SPECIFIC MINIMUM WAGE IN A TWO SECTOR HARRIS-TODARO MODEL.

$8213 \mathrm{C}$ Markusen, J.R. and Melvin, J.R. THE GAINS FROM TRADE THEOREM WITH INCREASING

8214C INDUSTRIAI ORGANIZATION AND THE GENERAL EQUILIBRIUM COSTS OF PROTECTION IN
SMALL OPEN BCONOMIES.

8215C Laidler, D. DID MACROECONOMICS NEED THE RATIONAL EXPECTATIONS REVOLUTION? 8216C Whalley, J. and WIgle, R. ARE DEVELOPED COUNTRY MULTLATERAL TARIFF
REDUCTIONS NECESSARILY BENEFICIAL FOR THE U.S.?

8217C Bade, R. and Parkin, M. Is STERLING M3 THE RIGHT AGGREGATE?

8218C Kosch, B. FIXED PRICE EQUIIIBRIA IN OPEN ECONOMIES.

1983

8301C Kimbell, L.J. and Harrison, G.W. ON THE SOLUTION OR GENERAL EQUILIBRIUM
MODELS.

8302C Melvin, J.R. A GENERAL BQUILIBRIUM ANALYSIS OF'.CANADIAN OIL POLICY.

8303C Markusen, J.R. and Svensson, L.E.O. TRADE IN COODS AND FACTORS WITH INTERNATIONAL DIFFERENCES IN TECHNOLOGY.

$8304 \mathrm{C}$ Mohammad, S. Whalley, J. RENT SEEKING IN INDIA: ITS COSTS AND POLICY
SIGNIFICANCE.

8305C DSU Jimenez, E. TENURE SECURITY AND URBAN SQUATTING.

8306C Parkin, $M$. WHAT CAN MACROECONOMIC THEORY TELL US ABOUT THE WAY DEFICITS
SHOULD BE MEASURED.

8307C Parkin, $M$. THE INFLATION DEBATE: AN ATTEMPT tO CLEAR THE AIR.

8308C Wooton, I. LABOUR MIGRATION IN A MODEL OF NORTH-SOUTH TRADE.

$8309 C$ Deardorff, A.V. THE DIRECTIONS OF DEVELOPING COUNTRIES TRADE: EXAMPLES
FROM PURE THEORY. 8310C Manning, $R$. ADVANTAGEOUS REALLOCATIONS AND MULTIPLE EQUILIBRIA:
FOR THE THREE-AGENT TRANSFER PROBLEM. 
8328C Boyer, Kenneth D. U.S.-CANADIAN TRANSPORTATION ISSUES.

8329C B1rd, Richard M. and Brean, Donald J.S. CANADA-U.S. TAX RELATIONS: ISSUES AND PERSPECTIVES.

$8330 \mathrm{C}$ Moroz, Andrew R. CANADA-UNITED STATES AUTOMOTIVE TRADE AND TRADE POLICY ISSUES.

8331C Grey, Rodney de C. and Curt18, John. INSTITUTIONAI ARRANGEMENTS FOR U.S.-CANADIAN NEGOTIATIONS. PART I: CANADA-U.S. TRADE AND ECONOMIC ISSUES: DO WE NEED A NEN INSTITUTION? PART II: INSTITUTIONAL ARRANGEMENTS FOR MANAGING THE CANADA-U.S. BCONOMIC RELATIONSHIP.

1984

8401C Harrison, Glenn $W$, and Manning, Richard. BEST APPROXIMATE AGGREGTION OF INPUT-OUTPUT SYSTEMS.

8402C Parkin, Michael. CORE INFLATION: A REVIEW ESSAY.

8403C Blomqvist, Ảke, and McMahon, Gary. SIMULATING COMMERICAI POLICY IN A SMALL, OPEN DUAL ECONOMY WITH URBAN UNEMPLOYMENT: A GENERAL EQUILIBRIUM APPROACH.

8404C Wonnacott, Ronald. THE THEORY OF TRADE DISCRIMINATION: THE IIIRROR IMAGE OF VINERIAN PREFERENCE THEORY?

8405C Whalley, John. IMPACTS OF A 50\% TARIFF REDUCTION IN AN EIGHT-REGION GLOBAL TRADE MODEL.

8406C Harrison, Glenn W. A GENERAL EQUILIBRIUM ANALYSIS OF TARIFT REDUCTIONS.

8407C Horstmann, Ignatius and Markusen, James R. STRATEGIC INVESTMENTS AND THE DEVELOPMENT OF MULTINATIONALS.

8408C Gregory, Allan $\mathrm{C}$. and McCurdy, Thomas H. TESTING THE UNBIASEDNESS HYPOTHESIS IN THE FORWARD FOREIGN EXCHANGE MARKET: A SPECIFICATION ANALYSIS.

8409C Jones, Ronald H. and Kierzkowsk1, Henryk. NEIGHBORHOOD PRODUCTION STRUCTURES WITH APPLICATIONS TO THE THEORY OF INTERNATIONAL TRADE.

$8410 \mathrm{C}$ Weller, Paul and Yano, Makoto. THE ROLE OF FUTURES MARKETS IN INTERNATIONAL TRADE: A GENERAL EQ̨UILIBRIUM APPROACH.

8411C Brecher, Richard A. and Bhagwat1, Jagdish N. VOLUNTARY EXPORT RESTRICTIONS VERSUS IMPORT RESTRICTIONS: A WELFARE-THEORETIC COMPARISON. 
$8412 \mathrm{C}$ Ethler, Wilfred J. ILLEGAL IMMIGRATION.

8413C Eaton, Jonathon and Gene M. Grossman. OPTIMAL TRADE AND INDUSTRIAL POLICY UNDER OLIGOPOLY.

$8414 \mathrm{C}$ Hooton, Ian. PREFERENTIAL TRADING AGREEMENTS - A $3 \mathrm{xn}$ MODEL.

8415C Park1n, M1chael. DISCRIMINATING BETWEEN KEYNESIAN AND CLASSICAL THEORIES OF THE BUSINESS CYCLE; JAPAN $1967-1982$

8416C Deardorff, Alan V. FIRless FIRwoes: HOW PREFERENCES CAN INTERFERE WITH THE THEOREMS OF INTERNATIONAL TRADE.

8417C Greenwood, Jeremy. NONTRADED GOODS, THE TRADE BALANCE, AND THE BAILANCE OF PAYNENTS.

8418C Blomqvist, Ake and Sharif Mohammad, CONTROLS, CORRUPTION, AND COMPETITIVE RENT-SEEKING IN LDCs.

8419C Grossman, Herschel I. POLICY, RATIONAL EXPECTATIONS, AND POSITIVE ECONOMIC ANALYSIS.

8420C Garber, Peter M. and Robert G. KIng. DEEP STRUCTURAL EXCAVATION? A CRITIOUUE OF EULER EQUATION METHODS.

$8421 \mathrm{C}$ Barro, Robert J. THE BEHAVIOR OF U.S. DEFICITS.

8422C Persson, Torsten and Lars E.0. Svensson. INTERNATIONAL BORROWING AND TIME-CONSISTENT FISCAL POLICY.

8423C Obstfeld Maurice. CAPItAL CONTROLS, THE DUAL eXchange RATE, AND DEVALUATION.

8.424C Kuhn, Peter. UNION PRODUCTIVITY EFFECTS AND ECONOMIC EFFICIENCY.

8425C Hamilton, Bob and John Whalley. TAX TREATMENT OF HOUSING IN A DYNAMIC SEOUENCED GENERAL EOUULIBRIUM MODEL.

:426C Hamilton, Bob, Shartf Mohammad, and John Whalley. RENT SEEKING AND THE NORTH-SOUTH TERMS OF TRADE.

8427C Adams, Charles and Jeremy Greenwood. DUAL EXCHANGE RATE SYSTEMS AND CAPITAL CONTROES: AN INVESTIGATION.

8428 Loh, Choon Cheong and Michael R. Veall. A NOTE ON SOCIAL SECURITY AND PRIVATE SAVINGS IN SINGAPORE.

8429 Whalley, John. REGRESSION OR PROGRESSION: THE TAXING OUESTION OF INCIDENCE ANALYSIS.

3430 Kuhn, Peter. WAGES, EFFORT, AND INCENTIVE-COMPATIBILITY IN LIFE-CYCLE EMPLOYMENT CONTRACTS. 
8431 Greenwood, Jeremy and Kent P. Kimbrough. AN INVESTIGATION IN THE THEORY OF FOREIGN EXCHANGE CONTROLS.

8432 Greenwood, Jeremy and Kent P. Kimbrough. CAPITAL CONTROLS AND THE INTERNATIONAL TRANSMISSION OF FISCAL POLICY.

8433 : Nguyen, Trien Trien and John Whalley. EṇUILIBRIUM UNDER PRICE CONTROLS WITH ENDOGENOUS TRANSACTIONS COSTS.

8434 Adams, Charles and Russell S. Boyer. EFFICIENCY AND A SIMPLE MODEL OF EXCHANGE RATE DETERMINATION.

8435 Kuhn, Peter. UNIONS, ENTREPRENEURSHIP, AND EFFICIENCY.

8436 Hercowitz, Zv1 and Efraim Sadka. ON OPTIMAL CURRENCY. SUBSTITUTION POLICY AND PUBLIC PINANCE.

8437 Lenjosek, Gordon and John Whalley, POLICY EVALUATION IN A SMALI OPEN PRICE TAKING ECONOMY: CANADIAN ENERGY POLICIES.

8438 Aschauer, David and Jeremy Greenwood. MACROECONOMIC EFFECTS OF FISCAL POLICY.

8439C Hercowitz, Zv1. ON THE DETERMINATION OF THE EXTERNAL DEBT: THE CASE OF ISRAEL.

8440C Stern, Robert M. GLOBAL DIMENSIONS AND DETERMINANTS OF INTERNATIONAL TRADE AND INVESTMENT IN SERVICES.

8441C Deardorff, Alan V. COMPARATIVE ADVANTAGE AND INTERNATIONAL TRADE AND INVESTMENT IN SERVICES.

8442C Daly, Donald J. TECHNOLOGY TRANSFER AND CANADA'S COMPETITIVE PERFORMANCE.

8443C Grey, Rodney de C. NEGOTIATING ABOUT TRADE AND INVESTMENT IN SERVICES.

8444C Grossman, Gene $M$. and Carl Shapiro. NORMATIVE ISSUES RAISED BY INTERNATIONAL TRADE IN TECHNOLOGY SERVICES.

3445C Chant, John $F$. THE CANADIAN TREATMENT OF FOREIGN BANKS: A CASE STUDY IN THE WORKINGS OF THE NATIONAL TREATMENT APPROACH.

8446C Aronson, Jonathan D. and Peter F. Cowhey. COMPUTER, DATA PROCESSING, AND COMMUNICATION SERVICES.

8447C Feketkkuty, Geza. NEGOTIATING STRATEGIES FOR LIBERALIZING TRADE AND INVESTMENT IN SERVICES.

8448C Harrison, Glenn, W. and E.E. Rutstrom. THE EFFECT OF MANUFACTURING SECTOR PROTECTION ON ASEAN AND AUSTRALIA: A GENERAL ENUILIBRIUM ANALYSIS. 
8502C Horstmann, Ignat1us and James R. Markusen. UP YOUR AVERAGE COST CURVE: INEFFICIENT ENTRY AND THE NEW PROTECTIONISM.

8503C Gregory, Allan W. TESTING INTEREST RATE PARITY AND RATIONAL EXPECTATIONS FOR CANADA AND THE UNITED STATES.

8504C Kuhn, Peter and Ian Hooton. INTERNATIONAL FACTOR MOVEMENTS IN THE PRESENCE OF A FIXED FACTOR.

8505C Nong, Kar-yiu. GAINS FROM GOODS TRADE AND FACTOR MOBILITY.

8506C Weller, Paul and Makoto Yano. FUTURES MARKETS, REAL INCOME, AND SPOT PRICE VARIABILITY: A GENERAL EOQUILIBRIUM APPROACH.

8507C Dlewert, V.E. THE EFPECTS OF AN INNOVATION: A TRADE THEORY APPROACH.

8508C Ethier, Wilfred J. POREIGN DIRECT INVESTMENT AND THE MULTINATIONAL FIRM.

8509C Dinopoulos, El1as. INSIDE THE BLACK BOX: (IN)TANGIBLE ASSETS, INTRA-INDUSTRY INVESTMENT AND TRADE.

8510C Jones, Richard, John Whalley, and Randall Higle. REGIONAL IMPACTS OF TARIFFS IN CANADA: PRELIMINARY RESULTS FROM A SMALL DIMENSIONAL NUMERICAL GENERAL EOUUILIBRIUM MODEL.

8511C Whalley, John. HIDDEN CHALLENGES IN RECENT APPLIED GENERAL EQ̨UILIBRIUM EXERCISES.

8512C Smith, Bruce. SOME COLONIAL EVIDENCE ON TWO THEORIES OF MONEY: MARYLAND AND THE CAROLINAS.

3513C Grossman, S.J., A. Melino, and R.J. Sh1ller. ESTIMATING THE CONTINUOUS TIME CONSUMPTION BASED ASSET PRICING MODEL.

8514C Romer, Paul R. TAX EFFECTS AND IRANSACTION COSTS FOR SHORT TERM MARKET DISCOUNT BONDS.

8515C McCallum, Bennett T. ON CONSEOUENCES AND CRITICISMS OP MONETARY TARGETING.

8516C Dinopoulos, Ellas and Ian Wooton. A NORTH-SOUTH MODEL OF INTERNATIONAL JUSTICE.

8517C Huffman, Gregory W. A DYNAMIC EQUILIBRIUM MODEL OF ASSET PRICES AND TRANSACTION VOLUME.

8518C Huffman, Gregory W. AN ALTERNATIVE VIEW OF OPTIMAL SEIGNIORAGE. 8519C Huffman, Gregory $W$. ASSET PRICING WITH HETERGENEOUS ASSETS. 


\section{$\underline{1985}$}

8520C Hercowitz, Zvi. THE REAL INTEREST RATE AND AGGREGATE SUPPLY.

8521C Davies, James and Michael Hoy. COMPARING INCOME DISTRIBUTIONS UNDER AVERSION TO DOWNSIDE INEQUALITY.

8522C Nguyen, Trien T, and John Whalley. COEXISTENCE OF EQUILIBRIA ON BLACK AND WHITE MARKETS.

8523C Clarete, Ramon and John Whalley. INTERACTIONS BETWEEN TRADE POLICIES AND DOMESTIC DISTORTIONS: THE PHILIPPINE CASE.

8524C Hamilton, Bob, Sharif Mohammad, and John Whalley. APPLIED GENERAL EQUILIBRIUM ANALYSIS AND PERSPECTIVES ON GROWTH PERFORMANCE.

8525C Huffman, Gregory $W$. THE LAGGED EFFECTS OF POLICY ON THE PRICE LEVEL.

8526C Laidler, David. FISCAL DEFICITS AND INTERNATIONAL MONETARY INST ITUTIONS.

8527C Goodfriend, Marvin. MONETARY MYSTIQUE: SECRECY AND CENTRAL BANKING.

8528C Nguyen, Trien T. and John Whalley. GENERAL EQUILIBRIUM ANALYSIS OF PRICE CONTROLS A TWO-SECTOR COMPUTATIONAL APPROACH.

$8529 \mathrm{C}$ Heckman, James $\mathrm{J}$. and $\mathrm{v}$. Joseph Hotz. AN INVESTIGATION OF THE LABOR MARKET EARNINGS OF PANAMANIAN MALES: EVALUATING SOURCES OF INEQUALITY. 